\title{
Development and Analysis of the Novel Hybridization of a Single-Flash Geothermal Power Plant with Biomass Driven $\mathrm{sCO}_{2}$-Steam Rankine Combined Cycle
}

\author{
Balkan Mutlu ${ }^{1,2, *(\mathbb{D})}$, Derek Baker ${ }^{1,2} \mathbb{D}$ and Feyza Kazanç ${ }^{1}(\mathbb{D}$ \\ 1 Department of Mechanical Engineering, Middle East Technical University, Ankara 06800, Turkey; \\ dbaker@metu.edu.tr (D.B.); fkazanc@metu.edu.tr (F.K.) \\ 2 Center for Solar Energy Research and Applications (GÜNAM), Ankara 06800, Turkey \\ * Correspondence: balkanmutlu@gmail.com
}

Citation: Mutlu, B.; Baker, D.; Kazanç, F. Development and Analysis of the Novel Hybridization of a Single-Flash Geothermal Power Plant with Biomass Driven $\mathrm{SCO}_{2}$-Steam Rankine Combined Cycle. Entropy 2021, 23, 766. https://doi.org/ $10.3390 / \mathrm{e} 23060766$

Academic Editor: Attila R. Imre

Received: 21 May 2021

Accepted: 7 June 2021

Published: 18 June 2021

Publisher's Note: MDPI stays neutral with regard to jurisdictional claims in published maps and institutional affiliations.

Copyright: (c) 2021 by the authors. Licensee MDPI, Basel, Switzerland. This article is an open access article distributed under the terms and conditions of the Creative Commons Attribution (CC BY) license (https:// creativecommons.org/licenses/by/ $4.0 /)$.

\begin{abstract}
This study investigates the hybridization scenario of a single-flash geothermal power plant with a biomass-driven $\mathrm{SCO}_{2}$-steam Rankine combined cycle, where a solid local biomass source, olive residue, is used as a fuel. The hybrid power plant is modeled using the simulation software EBSILON ${ }^{\circledR}$ Professional. A topping $\mathrm{sCO}_{2}$ cycle is chosen due to its potential for flexible electricity generation. A synergy between the topping $\mathrm{sCO}_{2}$ and bottoming steam Rankine cycles is achieved by a good temperature match between the coupling heat exchanger, where the waste heat from the topping cycle is utilized in the bottoming cycle. The high-temperature heat addition problem, common in $\mathrm{sCO}_{2}$ cycles, is also eliminated by utilizing the heat in the flue gas in the bottoming cycle. Combined cycle thermal efficiency and a biomass-to-electricity conversion efficiency of $24.9 \%$ and $22.4 \%$ are achieved, respectively. The corresponding fuel consumption of the hybridized plant is found to be $2.2 \mathrm{~kg} / \mathrm{s}$.
\end{abstract}

Keywords: hybridization; single-flash; geothermal; biomass; $\mathrm{SCO}_{2}$ cycle; olive residue; flexibility

\section{Introduction}

The performance of geothermal power plants can degrade over the years, as the geothermal resource is exploited. This degradation can be due to decreases in fluid temperature, flow rate, and pressure at the production wellhead over the lifetime of the geothermal resource. These decreases can reduce both the quantity (thermal energy) and quality (temperature) of the heat input, and lead to reductions in both the output and the thermal efficiency of the plant [1]. The performance of geothermal power plants is also typically negatively affected by increases in ambient temperatures, especially during the hot summer months. The power fluctuations due to the changes in ambient temperatures can exceed $20 \%$ in some scenarios [2]. The hybridization of geothermal resources with other renewable thermal energy resources offers the potential to increase the performance of geothermal power plants while being economically feasible, since the need for land and grid infrastructure can be reduced or eliminated. However, the hybridization of geothermal energy with other renewable thermal energy resources is a site-specific matter, due to the site-specific nature of the geothermal energy itself [3]. In the context of this article, Kizildere-1 (KZD-1), an existing single-flash Geothermal Electric Power Plant (GEPP), operating significantly below design capacity, is considered as a case study for hybridization with biomass energy. KZD-1 is located on the Western Anatolia region of Turkey, where Olive Residue (OR) exists as an abundant solid biomass resource. The hybridization scenario in this article concentrates on bringing the underutilized KZD-1 GEPP to its full capacity through the use of thermal heat derived from this local biomass source. The colocation of geothermal and biomass as a secondary renewable thermal energy source is exploited through utilizing the unused capacity of KZD-1 turbine and introducing a next-generation power cycle, i.e., 
supercritical $\mathrm{CO}_{2}\left(\mathrm{sCO}_{2}\right)$ cycle, as a topping cycle. A sCO $\mathrm{SCycle}_{2}$ is chosen for its potential to support flexible electricity generation. The article is structured to allow the method and outcomes to be adapted to other GEPP.

The interest in the hybridization of geothermal with biomass is limited in the literature. The state-of-the-art studies are limited to those using biomass-sourced heat to supplement the operating enthalpy of low-temperature geothermal [4], using biomass to compensate for the off-design conditions of a geothermal power plant [5], and multigeneration biogasgeothermal systems [6]. When the colocation of geothermal and agricultural lands or forestry are present, either biomass or geothermal is used to boost the performance of the other for actual industrial applications. For instance, a dry steam geothermal power plant in Cordia, Italy, operating below its rated output of $20 \mathrm{MWe}$, is redesigned to accommodate a biomass furnace in order to superheat the geothermal steam. An additional 5.4 MWe gain is obtained from the biomass combustion. In another example, a wood waste biomass power plant operating in close proximity to forest plantations in New Zealand is supplemented by a geothermal preheat [7].

Despite the limited studies on the hybridization of geothermal with biomass, the literature on hybridization of flash-type geothermal power plants with solar thermal is more developed [8] and can provide insight into the design of hybrid geothermal-biomass power plants. Solar thermal heat is used in most of these studies, either to preheat or superheat the geothermal working fluid. Initial efforts on hybrid solar-geothermal power plant models are by Lentz and Almanza [9,10], where a Direct Steam Generation (DSG) solar field is theoretically coupled to two different locations of the Cerro Prieto geothermal single flash plant in Mexico. In both of their proposed models, geothermal brine is allowed to pass through the tubes of a Parabolic Trough Collector (PTC) field with the purpose of increasing the flow rate of geothermal steam by $10 \%$. Mir et al. [11] developed a thermodynamic model to estimate the production of a hypothetical solar-geothermal power plant in Northern Chile for two different operational modes: (1) Peak Power mode with constant geothermal output where the solar input increases the power output; (2) Save Geothermal Resource mode with constant power output, and the use of geothermal resources decreases with increases in solar input. Note that, although individual authors often used different names for these modes, this naming is used for clarity and consistency within this section. Mir et al. [11] added solar heat to a single-flash geothermal power plant from a PTC field to produce superheated steam and additional saturated steam from the separator whenever possible. With the assistance of solar heat, up to an $11.6 \%$ increase in energy production from the geothermal brine is obtained for the Peak Power mode, whereas savings of up to $10.3 \%$ in the use of geothermal resources is obtained for the Save Geothermal Resource mode. Cardemil et al. [12] conducted energetic and exergetic analyses for hypothetical single- and double-flash geothermal power plants, with each having four different brine characteristics, taking Save Geothermal Resource and Peak Power modes into account. A PTC field is used to supply solar heat to the system after the separator, both to the geothermal brine and as additional steam and superheat, respectively. Their results show that a hybrid single-flash power plant can produce at least $20 \%$ additional power output, depending on the brine characteristics. For all the analyzed cases, at least a 3\% increase is observed for first law efficiencies. For the Save Geothermal Resource mode, where the plant power output stays constant when solar resources are available, $16 \%$ and $19 \%$ reductions in geothermal fluid consumption are observed for flash and double-flash configurations, respectively. A more recent and comprehensive study on the hybridization of flash-type geothermal power plants is conducted by McTigue et al. [13]. In their study, an existing double-flash power plant operating in China Lake, California, is hybridized with solar thermal to increase the power generation. It aimed to increase the power output of the geothermal turbine operating at $75 \%$ of its rated output $(22.5 \mathrm{MW})$ to $100 \%$ of its rated output (30 MW) by integrating an array of PTCs. In order to decide the optimum point for solar thermal heat addition from the PTC heat transfer fluid to the double-flash geothermal power plant, parametric analyses of thermal efficiency are compared for four different 
points within the double-flash GEPP. The optimum point for heat addition is found to be the brine after the first flash tank separator. The solar heat added to this brine is converted to electricity with an efficiency of $24.3 \%$. Alternate thermal storage scenarios are also investigated for dispatchable electricity generation. Overall, the Levelized Cost of Electricity (LCOE) with $3 \mathrm{~h}$ of thermal energy storage is calculated as $0.08 \$ / \mathrm{kWhe}$, which is lower than the equivalent conventional standalone CSP and battery integrated PV systems. It is concluded that hybridization can be cost-effective, since the existing power block, pipework, and condenser are shared.

A novel hybrid solar integration for a binary-type geothermal plant has been proposed by Bonyadi et al. [14]. Although binary plants have different characteristics to flash type plants, their introduction of a topping cycle for hybridization formed the inspiration for the efforts in this article. Bonyadi et al. [14] added a solar-powered steam Rankine topping cycle to a hypothetical binary geothermal power plant, without requiring any physical modification or deviation from design conditions of the bottoming Organic Rankine Cycle (ORC). The solar topping cycle is coupled to the ORC so that the waste heat from the topping cycle is utilized in the ORC. Their representative design has an incremental solar efficiency of $12.2 \%$ for Peak Power mode and consumes up to $17 \%$ less brine than a similar stand-alone geothermal plant for the Save Geothermal Resource mode.

For the completely different technology of Enhanced Geothermal System (EGS), Jiang et al. [15] integrated solar thermal heat into a hypothetical EGS where $\mathrm{CO}_{2}$ is used as both heat transmission fluid for geothermal and working fluid for the $\mathrm{SCO}_{2}$ power cycle. Their hybrid system uses geothermal energy as the primary energy source to provide the base-load electricity, and the solar energy is used as a supplement to meet the peak demand whenever possible. Their hybrid plant reaches the maximum thermal efficiency of $22.44 \%$ for a $\mathrm{CO}_{2}$ turbine inlet temperature of $600{ }^{\circ} \mathrm{C}$.

The $\mathrm{sCO}_{2}$ cycle studied in this article is a part-flow type $\mathrm{sCO}_{2}$ cycle. Despite the equivalent or higher thermodynamical efficiencies of $\mathrm{sCO}_{2}$ cycles compared to their steam Rankine counterparts, there has not been a full-scale commercial demonstration of the $\mathrm{sCO}_{2}$ cycles as the studies are limited to laboratory-scale test setups under $1 \mathrm{MW}$ [16-19]. The underlying reason for $\mathrm{SCO}_{2}$ cycles offering good thermal efficiency is that the compression work of $\mathrm{CO}_{2}$ as a working fluid close to its critical point of $31.1^{\circ} \mathrm{C}$ and $7.39 \mathrm{MPa}$ is minimal [20]. However, thermophysical properties of $\mathrm{CO}_{2}$, such as the isobaric heat capacity in the vicinity of its critical point, exhibit non-linear behavior and result in a pinch-point problem. Utamura [21] demonstrated that a first law efficiency of $45 \%$ under maximum operating conditions of $20 \mathrm{MPa}$ and $526.9^{\circ} \mathrm{C}$ is achievable for part-flow $\mathrm{sCO}_{2}$ cycles where the pinch-point problem can be avoided. The part-flow configuration helps to confine the likelihood of pinch-point problems to the low-temperature recuperator (LTR) by splitting the rest of the recuperation process to a high-temperature recuperator (HTR). Overall, part-flow $\mathrm{sCO}_{2}$ cycles can offer a more than $5 \%$ increase in the thermal efficiency compared to simple recuperated $\mathrm{sCO}_{2}$ cycles, and are the most extensively researched $\mathrm{sCO}_{2}$ cycle in the literature, as they are relatively simple and retain good efficiency [22]. In addition to the pinch-point problem, the $\mathrm{sCO}_{2}$ cycles have another intrinsic problem regarding the heat addition to the cycle. Due to their highly recuperative characteristics, the external heat addition to $\mathrm{sCO}_{2}$ cycles is carried out over a high-temperature interval [23-25]. To overcome this limitation, the $\mathrm{SCO}_{2}$ cycles are often combined with bottoming ORC cycles operating at low temperatures [26-29], or utilized in cascading manner as $\mathrm{sCO}_{2}-\mathrm{sCO}_{2}$ and $\mathrm{sCO}_{2}$-transcritical carbon dioxide $\left(\mathrm{tCO}_{2}\right)$ cycles [23-25]. Alternatively, for coal-powered $\mathrm{sCO}_{2}$ cycle designs, advanced boiler and heater designs are introduced to fully exploit the available heat in the flue gas within the cycle, at the cost of obtaining more complex layouts [30,31]. Motivated by the problem of a biomass-powered $\mathrm{sCO}_{2}$ cycle design, Manente and Lazzaretto [32] introduced a novel cascaded $\mathrm{sCO}_{2}$ cycle configuration using woody biomass as a fuel. In their study, two different cascaded $\mathrm{sCO}_{2}$ cycles, namely part-flow-simple-recuperated and simplerecuperated-simple-recuperated, are investigated, along with four different biomass boiler arrangements. Their results showed that part-flow-simple-recuperated cascaded $\mathrm{sCO}_{2}$ 
cycle design with a counter-current radiative-convective boiler demonstrated the best performance in terms of biomass-to-electricity conversion efficiency, i.e., either $34 \%$ or $36 \%$, depending on the presence of an air-preheating unit, for the topping cycle turbine inlet temperature (TIT) of $550^{\circ} \mathrm{C}$.

The work in this article aims to build on this existing literature by presenting a novel scheme to hybridize an existing single-flash GEPP with biomass-derived heat that can be adapted to any site where colocation of these two renewable resource types is present. KZD-1 is used as a case study to apply this novel method and analyze its performance.

\section{Novel Hybrid Geothermal-Biomass Power Plant Scheme}

Based on the reviewed literature, for an existing flash type GEPP suffering from a degradation in its geothermal resource in terms of a decreased flow rate or enthalpy, which ultimately causes a reduced steam flow to its turbine, the following novel hybrid geothermal-biomass hybridization scheme can be adapted if colocated with a solid biomass resource. A part-flow $\mathrm{sCO}_{2}$ cycle, to be operated at a higher temperature than the existing geothermal cycle, can be used as a topping cycle. The part-flow $\mathrm{sCO}_{2}$ cycle can reject its waste heat through its cooler to preheat the condensate of the existing geothermal cycle. A novel biomass heater-boiler designed for this unique application can supply high-temperature heat from biomass combustion through radiative heat transfer to drive the part-flow $\mathrm{sCO}_{2}$ topping cycle, and bring the preheated geothermal condensate to a certain steam quality. The medium-temperature heat of the flue gas is transferred to this steam-water mixture by means of convective heat transfer to create dry steam. This 100\% biomass-energy-derived dry steam can be fed to the steam turbine of an existing GEPP operating under capacity due to a reduction in its mass flow. Moreover, when appropriate, the existing unused cooling component capacity of GEPP can be used to condensate the biomass derived steam exhaust for better utilization. Such a novel hybridization scheme offers several advantages. First, the rejected heat of the topping $\mathrm{sCO}_{2}$ cycle is not lost, but instead used to supply heat for an additional dry steam. Second, $\mathrm{SCO}_{2}$ cycles are either utilized in a cascaded manner [23-25,32] or combined with ORC bottoming cycles operating at low temperatures [26-29] due to their high-temperature heat requirement. Since the medium temperature heat of the flue gas is used for the creation of additional dry steam, the need to use an additional bottoming ORC or $\mathrm{sCO}_{2}$ cycle is eliminated. As a result, the existing GEPP can be brought to full capacity to allow for better Capex utilization. Note that only the unused flow capacity of steam turbine and, if possible, an existing cooling system is used for such a hybridization scenario, while operational steam turbine inlet conditions, i.e., pressure and temperature, remain unchanged. In this sense, hybridization is possible without modifying the components of the existing GEPP.

\subsection{Application of Proposed Novel Hybridization Scheme to KZD-1 GEPP}

\subsubsection{Existing Conditions of KZD-1 GEPP}

KZD-1 GEPP is the first geothermal power plant in Turkey, commissioned in 1984 and currently operated by Zorlu Energy [33]. The steam mass flow rate feeding the steam turbine of KZD-1 decreased significantly over the years, considering the differences between the current mass flow rate of $19.45 \mathrm{~kg} \mathrm{~s}^{-1}$ and the average steam mass flow rate of $33.34 \mathrm{~kg} \mathrm{~s}^{-1}$ reported by Gökçen et al. in 2004 [34]. Moreover, the steam turbine of KZD-1 seems to have been worn out over its active years, considering its current calculated isentropic efficiency of $30 \%$ and reported isentropic efficiencies of $71.2 \%$ and $71.5 \%$ in the literature $[33,34]$. In order to better represent single-flash GEPPs and make the hybridization efforts meaningful, within the context of this article, the isentropic efficiency of the steam turbine is assumed to be $80 \%$, in line with the typical isentropic efficiencies of geothermal steam turbines suggested by DiPippo [33].

KZD-1 is a typical single-flash GEPP with multiple production wells; its schematic is supplied in Figure 1. Although a non-condensable gas (NCG) extraction system exists in reality, it is excluded within the context of this article in order to focus on thermodynamic 
modeling. After the two-phase geothermal brines were collected and flashed to $0.438 \mathrm{MPa}$ and $146.9^{\circ} \mathrm{C}$, the geothermal brine and steam were separated through the high-pressure (HP) separator. The geothermal brine was used for district heating before being directed to the neighboring Kizlldere-2 (KZD-2) GEPP's low-pressure (LP) separator, where it was ultimately re-injected. The geothermal steam after the HP separator reached $146.91{ }^{\circ} \mathrm{C}$, with a flow rate of $19.45 \mathrm{~kg} \mathrm{~s}^{-1}$; it then passed through the steam turbine and the exhaust steam was condensed through the direct contact (DC) steam condenser. The condensed steam was then pumped to the wet cooling tower (WCT), where it was used as a cooling water and ultimately evaporated. The WCT used no make-up water, since the geothermal condensate was used as cooling water.

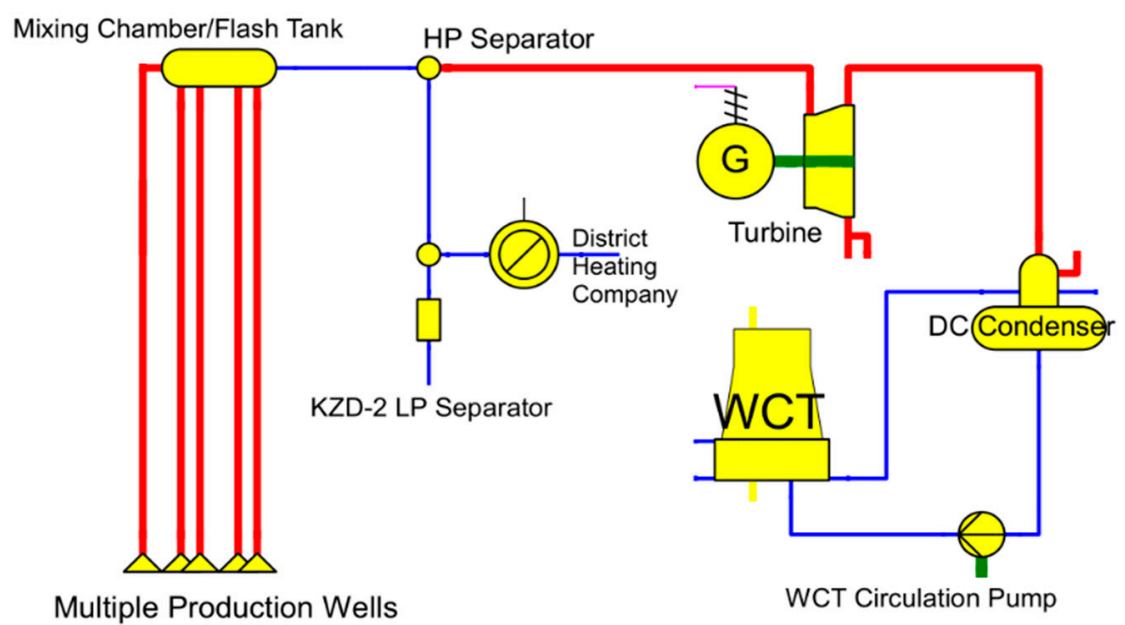

Figure 1. Existing schematic of KZD-1 GEPP, as drawn in EBSILON ${ }^{\circledR}$ Professional.

\subsubsection{Biomass Fuel Source}

KZD-1 GEPP is located on the border of two western Anatolian cities of Turkey, Aydın and Denizli. In this region, the olive oil sector is well-developed [35]. Olive residue (OR) is a by-product of olive oil production and found abundantly in the region, where it is mostly used for domestic heating [36]. To exploit the synergistic colocation of the two renewable energy resources, OR samples from a nearby olive oil factory, KZD-1 GEPP, were collected. The results of the conducted analyses of the OR are presented in Table 1.

Table 1. Analysis of the biomass fuel.

\begin{tabular}{|c|c|}
\hline Parameter & \\
\hline \multicolumn{2}{|l|}{ Proximate analysis (wt. $\%$, dry basis) } \\
\hline Volatile matter & 83.9 \\
\hline Fixed Carbon ${ }^{a}$ & 14.2 \\
\hline Ash & 1.9 \\
\hline \multicolumn{2}{|l|}{ Moisture content (wt. $\%$, as received) } \\
\hline Moisture & 7.5 \\
\hline \multicolumn{2}{|l|}{ Ultimate analysis (wt.\%, dry ash free) } \\
\hline $\mathrm{C}$ & 51.5 \\
\hline $\mathrm{H}$ & 6.2 \\
\hline $\mathrm{N}$ & 0.7 \\
\hline $\mathrm{S}$ & - \\
\hline $\mathrm{O}^{\mathrm{a}}$ & 41.6 \\
\hline \multicolumn{2}{|l|}{ Calorific value } \\
\hline Higher heating value (dry basis) ${ }^{\mathrm{b}}\left(\mathrm{MJ} \mathrm{kg}^{-1}\right)$ & 20.5 \\
\hline Lower heating value (wet basis) ${ }^{\mathrm{c}}\left(\mathrm{MJ} \mathrm{kg}^{-1}\right)$ & 17.5 \\
\hline
\end{tabular}


The higher heating value (HHV) of the biomass fuel was calculated based on its ultimate analysis following the procedure supplied by Sheng and Azevedo [37]. A lower heating value (LHV) was calculated from the HHV, in parallel with the work of Manente and Lazzaretto [32]. As a cross-check for HHV, Magãlhaes et al. [38] reported the HHV of their OR sample collected from the Balıkesir region of Turkey as $20.11 \mathrm{MJ} \mathrm{kg}^{-1}$, which is in good agreement with the calculated HHV for the OR samples used in this article. The ultimate analysis and heating values of the biomass fuel were used as inputs to simulation software EBSILON ${ }^{\circledR}$ Professional where the hybrid power plant is modeled.

\subsubsection{Model Development}

A thermodynamic model was developed using EBSILON ${ }^{\circledR}$ Professional software for the application of the proposed novel hybridization scheme to KZD-1 GEPP. The thermodynamic concepts of the associated model are highlighted in Figure 2. The proposed hybrid scheme consists of the following three cycles:

1. BTC: Biomass combustion driven $\mathrm{sCO}_{2}$ Topping Cycle;

2. BBC: Bottoming Biomass combustion and topping cycle waste, heat-driven steam Rankine Cycle;

3. EGC: Existing open-loop steam Rankine cycle, driven by geothermal energy (EGC).

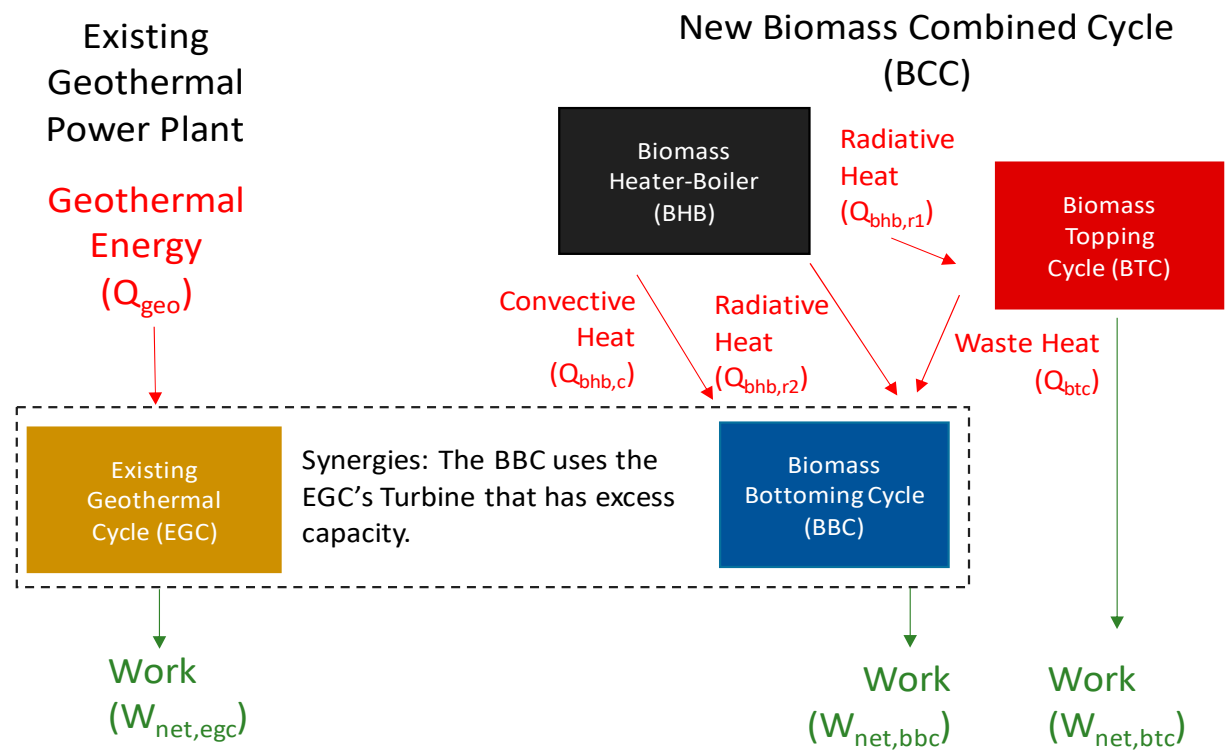

Figure 2. Thermodynamic conceptualization of proposed hybrid power plant.

Here, a combination of BTC and BBC forms the new biomass combined cycle (BCC). Note that the conceptualization in Figure 2 is strictly for thermodynamic modeling and enables the thermal efficiencies for the BCC, BTC, and BBC to be calculated.

In terms of thermodynamic modeling, the most prominent feature of the existing KZD1 GEPP is that it utilizes an open-loop (not cyclic) steam Rankine cycle, since the condensate outlet of the DC condenser is used as cooling water in WCT and eventually lost due to evaporation. The flow rate of this lost cooling water is equal to the original geothermal steam, separated by the HP separator, which then passes through the steam turbine of KZD-1, as shown in Figure 1. Due to this condition of the KZD-1 GEPP, sharing of the unused capacity of the existing cooling system is specifically avoided. In other words, the existing cooling system of KZD-1 is not used, to avoid the eventual loss of biomass-derived dry steam through the WCT. For this purpose, a hypothetical steam Rankine bottoming cycle (BBC) was introduced to form a closed-loop biomass combined cycle (BCC) along with the biomass topping cycle (BTC). Although the hypothetical BBC and EGC are shown separately in Figure 2, they are not physically separate, as both cycles share the existing steam turbine of KZD-1. Specifically, BBC is a theoretical construct to model a closed-loop 
BCC. While BTC rejects its waste heat to BBC, as shown in Figure 2, heat rejection from $\mathrm{BBC}$ is to the surroundings and achieved by means of a hypothetical dry cooling system, shown in the overall hybrid power plant layout in Figure 3.

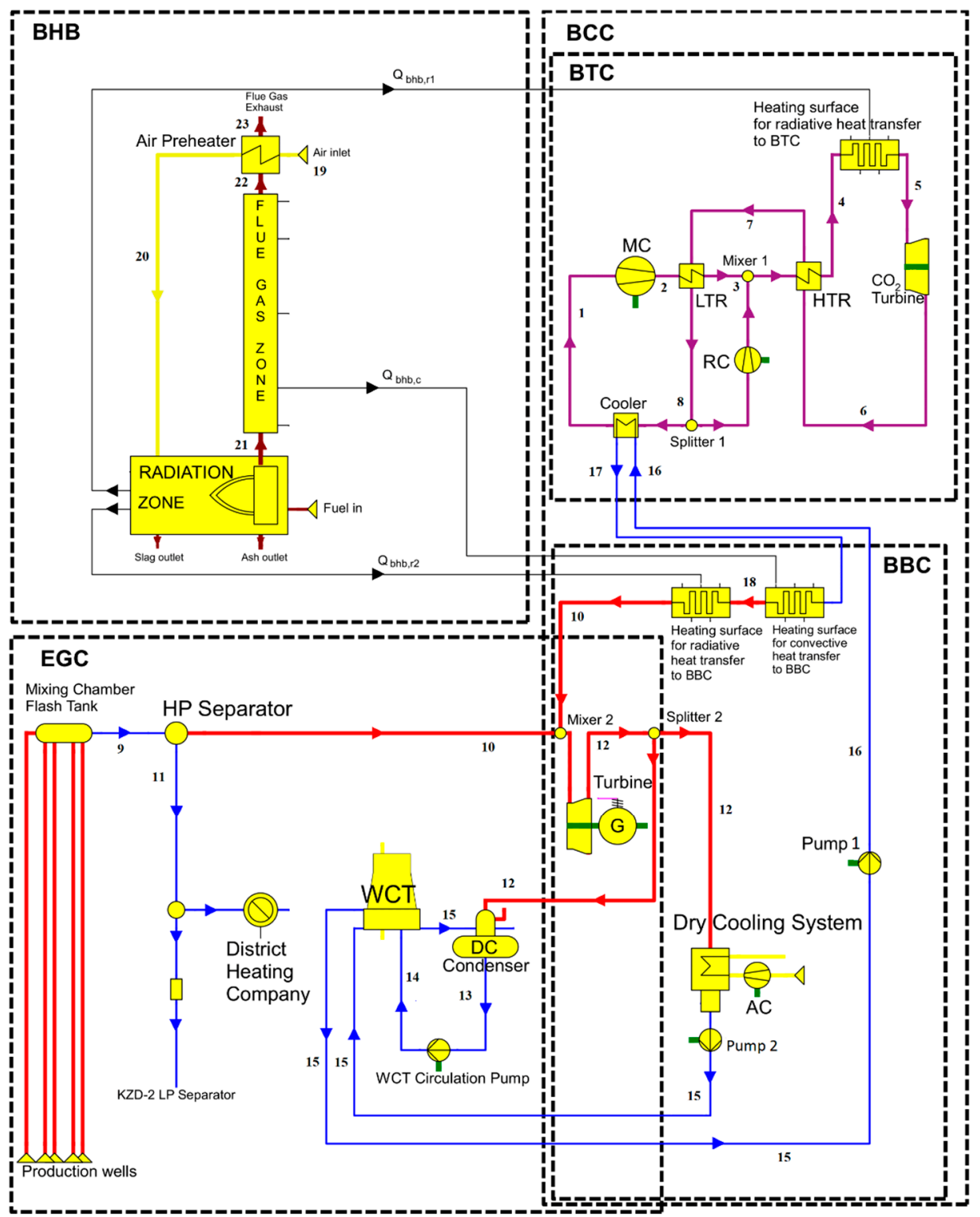

Figure 3. Schematic of the developed hybrid plant in EBSILON ${ }^{\circledR}$ Professional.

If EGC were to be a closed-loop cycle, there would be no need to construct the hypothetical BBC, since EGC could be used as the bottoming cycle. Overall, application of the proposed novel hybridization scheme to KZD-1 GEPP resulted in two hypothetical cycles, i.e., BTC and BBC, whose combination constitutes a fully biomass-driven, closedloop combined cycle, BCC. The configuration of the hybrid plant is presented in Figure 3.

The topping part-flow $\mathrm{sCO}_{2}$ cycle used for hybridization (BTC) was adapted from the work of Utamura [21]. The characteristics of the optimized BTC are presented in Table 2. The turbine inlet condition is fixed at $550{ }^{\circ} \mathrm{C}$ and $20 \mathrm{MPa}$ to be parallel with the part-flow $\mathrm{sCO}_{2}$ cycles designs in the literature [32,39-43]. The heat rejection from BTC was transferred the BBC through the cooler. Heat input to BTC was achieved by means of radiative heat transfer from the biomass heater-boiler (BHB). 
Table 2. Constants and inputs for the proposed hybrid plant.

\begin{tabular}{|c|c|c|c|c|}
\hline Input & Value & Unit & Description & Source/Comment \\
\hline \multicolumn{5}{|l|}{ BTC } \\
\hline$\eta_{\text {comp }}$ & 90 & $\%$ & $\begin{array}{l}\text { Isentropic efficiency of the } \\
\text { compressors }\end{array}$ & {$[21,32]$} \\
\hline$\eta_{\text {turb }}$ & 93 & $\%$ & Isentropic efficiency of the turbine & {$[21,31,44]$} \\
\hline $\mathrm{T}_{\text {turb }}$ & 550 & ${ }^{\circ} \mathrm{C}$ & Turbine inlet temperature & {$[22,32,42,45]$} \\
\hline $\mathrm{P}_{\text {turb }}$ & 20 & $\mathrm{MPa}$ & Turbine inlet pressure & [21] \\
\hline$\varphi$ & 3 & - & $\begin{array}{l}\text { Expansion ratio of the } \mathrm{CO}_{2} \text { turbine, } \\
\qquad \mathrm{P}_{5} / \mathrm{P}_{6}\end{array}$ & $\begin{array}{l}\text { Optimized parameter } \\
\text { [21]. }\end{array}$ \\
\hline$\psi$ & 0.75 & - & Part-flow ratio, $\dot{\mathrm{m}}_{1} / \dot{\mathrm{m}}_{8}$ & $\begin{array}{l}\text { Optimized parameter } \\
\text { [21]. }\end{array}$ \\
\hline $\mathcal{E}_{\text {recup }}$ & 96 & $\%$ & Effectiveness of the recuperators & {$[21,39,46]$} \\
\hline$\varepsilon_{\text {cooler }}$ & 80 & $\%$ & Effectiveness of the cooler & {$[21,46]$} \\
\hline$\Delta \mathrm{P}_{\text {hot,recup }}$ & 0.03 & $\mathrm{MPa}$ & $\begin{array}{l}\text { Pressure drop at hot side of } \\
\text { recuperators }\end{array}$ & {$[21,47]$} \\
\hline$\Delta \mathrm{P}_{\text {cold,recup }}$ & 0.22 & $\mathrm{MPa}$ & $\begin{array}{l}\text { Pressure drop at cold side of } \\
\text { recuperators }\end{array}$ & {$[21,47]$} \\
\hline$\Delta \mathrm{P}_{\text {hot, cooler }}$ & 0.6 & $\mathrm{MPa}$ & Pressure drop at hot side of cooler & {$[21,47]$} \\
\hline$\Delta \mathrm{P}_{\text {cold,cooler }}$ & r 0.1 & $\mathrm{MPa}$ & Pressure drop at cold side of cooler & {$[21,47]$} \\
\hline $\begin{array}{l}\Delta \mathrm{P}_{\mathrm{bhb}, \mathrm{co} 2} \\
\mathrm{BBC}\end{array}$ & 0.24 & $\mathrm{MPa}$ & Pressure drop for $\mathrm{CO}_{2}$ inside $\mathrm{BHB}$ & {$[21,47]$} \\
\hline$\eta_{\text {turb,bot }}$ & 80 & $\%$ & $\begin{array}{c}\text { Isentropic efficiency of the steam } \\
\text { turbine }\end{array}$ & $\begin{array}{l}\text { Assumption. See } \\
\text { Section 2.1.1 }\end{array}$ \\
\hline$\eta_{\text {pump }}$ & 80 & $\%$ & Isentropic efficiency of the pumps & Generic value. \\
\hline$\eta_{\text {air comp }}$ & 90 & $\%$ & $\begin{array}{c}\text { Isentropic efficiency of the air } \\
\text { compressor }\end{array}$ & Generic value. \\
\hline $\mathrm{T}_{\text {turb,bot }}$ & 146.9 & ${ }^{\circ} \mathrm{C}$ & Turbine inlet temperature & Operational KZD-1 data. \\
\hline$P_{\text {turb }}$ & 0.438 & $\mathrm{MPa}$ & Turbine inlet pressure & Operational KZD-1 data. \\
\hline $\begin{array}{l}\Delta \mathrm{P}_{\text {bhb,water }} \\
\mathrm{BHB}\end{array}$ & 0.01 & $\mathrm{MPa}$ & Pressure drop for water inside $\mathrm{BHB}$ & Generic value. \\
\hline$\lambda$ & 1.5 & - & Excess air ratio & {$[32]$} \\
\hline TEF & 1000 & ${ }^{\circ} \mathrm{C}$ & Effective temperature of radiation & [32] \\
\hline $\begin{array}{l}\text { Rad. } \\
\text { loss }\end{array}$ & 5 & $\%$ & $\begin{array}{l}\text { Heat loss in the radiative section of } \\
\text { BHB }\end{array}$ & [32] \\
\hline$\varepsilon_{\text {air preheater }}$ & 80 & $\%$ & Effectiveness of the air preheater & [46] \\
\hline $\mathrm{T}_{\text {air,in }}$ & 20 & ${ }^{\circ} \mathrm{C}$ & $\begin{array}{c}\text { Air inlet temperature to air } \\
\text { preheater }\end{array}$ & [32] \\
\hline
\end{tabular}

Since the existing steam Rankine cycle, driven by geothermal energy (EGC), is openloop and has the operating conditions mentioned in Section 2.1.1, a new, closed-loop, hypothetical steam Rankine cycle (BBC), driven by biomass heat and waste heat from BTC, was developed as follows. The working fluid, water at $0.1 \mathrm{MPa}$ and $29^{\circ} \mathrm{C}$ (State 15), was taken from the basin of the KZD-1 WCT and pumped to a slightly higher pressure than the steam turbine inlet pressure (State 16) to account for the subsequent pressure losses. Using the rejected heat from BTC via its cooler, water was sensibly preheated to a temperature of $127.7^{\circ} \mathrm{C}$ (State 17), close to its saturation temperature of $146.9^{\circ} \mathrm{C}$. The preheated water at State 17 was heated with the radiation from the biomass combustion until it reached $40 \%$ steam quality (State 18) and was brought to dry steam phase (State 10) by the convective heat transfer from the flue gas. Then, it was mixed with the geothermal steam at Mixer 2 and allowed to pass through the steam turbine. After passing through the turbine, the biomass-sourced fraction of the exhaust steam was extracted through the Splitter 2 (State 12), condensed, and sensibly cooled via the hypothetical dry cooling system, before being pumped into the basin of the WCT at the same thermodynamic state it was originally taken from (State 15). The partial extraction of steam exhaust at Splitter 2 and its dry cooling were carried out to avoid water consumption and create a closed-loop steam Rankine cycle, BBC. EGC and BBC are not physically separate, as both cycles use the same steam turbine. The co-occurrence of these two cycles starts at Mixer 2 and lasts 
until the biomass-derived portion of the steam exhaust is extracted through Splitter 2 at State 12 . BBC is used to provide additional dry steam to the steam turbine which, before hybridization, is operating under capacity. Since the heat supplied to BBC is purely derived from biomass, the additional power production of the steam turbine is due to the addition of dry steam and is attributed to the BBC.

The radiative-convective, counter-current heater configuration from the work of Manente and Lazzaretto is modified and adapted for use in this article to drive both BTC and $\mathrm{BBC}$ [32]. Since the biomass combustion heat is used to add heat to the supercritical working fluid of $B T C$, and to create dry steam for $B B C$, this heating element is named the Biomass Heater and Boiler (BHB). An alternative schematic of the BHB is shown in Figure 4 with state numbers compatible with Figure 3. BHB can be considered as a discrete element from the cycles whose role is to supply the heat required by BTC and BBC. The radiation from the biomass combustion is used to add heat to $B T C$ inside the radiative section of BHB. As described above, the working fluid of BBC, water, which was previously preheated through the BTC cooler, is brought to $40 \%$ steam quality using the radiation from the combustion in the radiative section of BHB. The water-steam mixture at $40 \%$ steam quality was then brought to the dry steam phase by means of convective heat transfer from the flue gas, before being mixed with the geothermal steam in Mixer 2. The remaining low-temperature useful heat in the flue gas was recovered using a counter-current air preheater. Finally, the flue gas was sent to the exhaust at $110^{\circ} \mathrm{C}$, which is greater than the dew point, to prevent condensation.

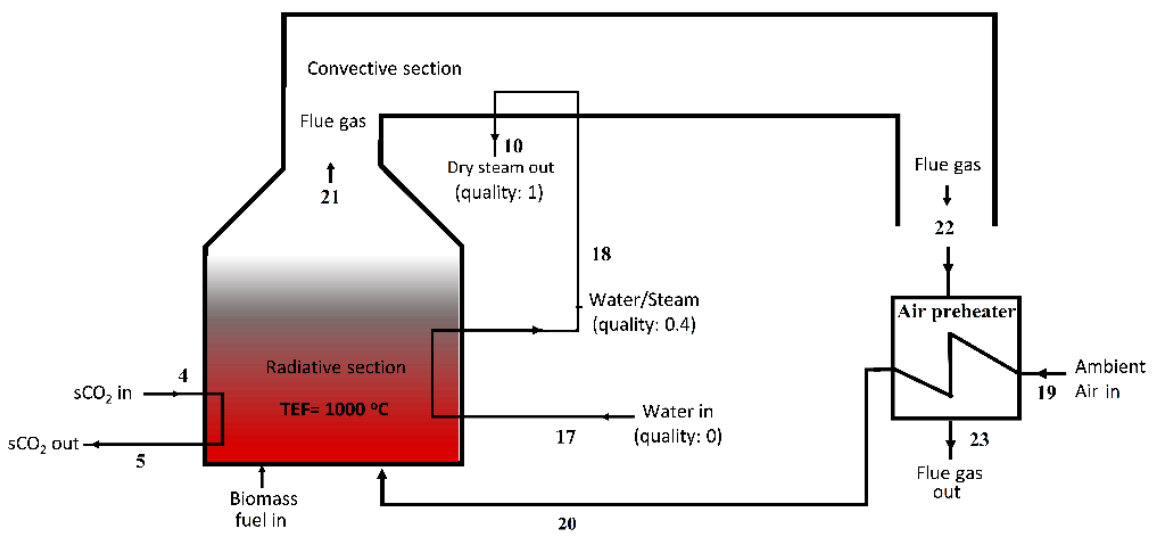

Figure 4. Radiative-convective counter-current heater-boiler (BHB) layout.

\subsubsection{Energy Analysis}

The thermodynamic modeling of the proposed hybrid configuration in Figure 3 was performed using EBSILON ${ }^{\circledR}$ Professional software and its EbsBoiler module. The design conditions and characteristics of the components are presented in Table 2. Due to the novelty of the proposed hybrid configuration, the well-known energetic performance parameters are slightly different from their standalone definitions and are defined as follows.

The heat inputs to cycles shown in Figure 2 are defined sequentially as

$$
\begin{gathered}
\dot{\mathrm{Q}}_{\mathrm{bhb}, \mathrm{r} 1}=\dot{\mathrm{m}}_{4}\left(\mathrm{~h}_{5}-\mathrm{h}_{4}\right) \\
\dot{\mathrm{Q}}_{\mathrm{bhb}, \mathrm{r} 2}=\dot{\mathrm{m}}_{17}\left(\mathrm{~h}_{18}-\mathrm{h}_{1}\right) \\
\dot{\mathrm{Q}}_{\mathrm{bhb}, \mathrm{c}}=\dot{\mathrm{m}}_{17}\left(\mathrm{~h}_{18}-\mathrm{h}_{17}\right) \\
\dot{\mathrm{Q}}_{\mathrm{btc}}=\dot{\mathrm{m}}_{17}\left(\mathrm{~h}_{17}-\mathrm{h}_{16}\right)
\end{gathered}
$$

where $\dot{\mathrm{Q}}_{\mathrm{bhb}, \mathrm{r} 1}$ and $\dot{\mathrm{Q}}_{\mathrm{bhb}, \mathrm{r} 2}$ are the radiative heat transfer from $\mathrm{BHB}$ to $\mathrm{BTC}$ and $\mathrm{BBC}$, respectively. While $\dot{\mathrm{Q}}_{\mathrm{bhb}, \mathrm{c}}$ represents the convective heat transfer from $\mathrm{BHB}$ to $\mathrm{BBC}, \dot{\mathrm{Q}}_{\mathrm{btc}}$ represents the waste heat rejection from BTC cooler to BBC. 
The net power outputs of the cycles are defined as

$$
\begin{gathered}
\dot{\mathrm{W}}_{\text {net,btc }}=\dot{\mathrm{W}}_{\text {turb,btc }}-\dot{\mathrm{W}}_{\mathrm{MC}, \mathrm{btc}}-\dot{\mathrm{W}}_{\mathrm{RC}, \mathrm{btc}} \\
\dot{\mathrm{W}}_{\text {net,bbc }}=\dot{\mathrm{W}}_{\text {turb,bbc }}-\dot{\mathrm{W}}_{\text {drycoolingsys,bbc }} \\
\dot{\mathrm{W}}_{\text {net,bcc }}=\dot{\mathrm{W}}_{\text {net,bbc }}+\dot{\mathrm{W}}_{\text {net,btc }}
\end{gathered}
$$

Consequently, the thermal efficiencies are calculated as

$$
\begin{gathered}
\eta_{\mathrm{btc}}=\frac{\dot{\mathrm{W}}_{\text {net,btc }}}{\dot{\mathrm{Q}}_{\mathrm{bhb}, \mathrm{r} 1}} \\
\eta_{\mathrm{bbc}}=\frac{\dot{\mathrm{W}}_{\mathrm{net}, \mathrm{bbc}}}{\eta_{\mathrm{bcc}}=\frac{\dot{\mathrm{W}}_{\mathrm{bhb}, \mathrm{bcc}}+\dot{\mathrm{Q}}_{\mathrm{bhb}, \mathrm{c}}+\dot{\mathrm{Q}}_{\mathrm{btc}}}{\dot{\mathrm{Q}}_{\mathrm{bhb}, \mathrm{r} 1}+\dot{\mathrm{Q}}_{\mathrm{bhb}, \mathrm{r} 2}+\dot{\mathrm{Q}}_{\mathrm{bhb}, \mathrm{c}}}}
\end{gathered}
$$

Note that $\dot{\mathrm{Q}}_{\mathrm{btc}}$ is not present in the denominator of Equation (10) due to its representing an internal heat transfer within the combined cycle, BCC.

The biomass heater-boiler (BHB) efficiency, representing the efficiency of the heat transfer from chemical biomass energy to $\mathrm{BCC}$, is defined in terms of a direct method as

$$
\eta_{\mathrm{bhb}}=\frac{\dot{\mathrm{Q}}_{\mathrm{bhb}, \mathrm{r} 1}+\dot{\mathrm{Q}}_{\mathrm{bhb}, \mathrm{r} 2}+\dot{\mathrm{Q}}_{\mathrm{bhb}, \mathrm{c}}}{\dot{\mathrm{m}}_{\text {fuel }} \mathrm{LHV}_{\text {fuel }}}
$$

where $\dot{\mathrm{m}}_{\text {fuel }}$ and $\mathrm{LHV}$ fuel are the biomass fuel consumption and LHV of the biomass fuel, respectively.

Finally, the biomass-to-electricity conversion efficiency, $\eta_{\mathrm{b} 2 \mathrm{e}}$, can either be found with the multiplication of $\eta_{\mathrm{bcc}}$ and $\eta_{\mathrm{bhb}}$, or explicitly from

$$
\eta_{\mathrm{b} 2 \mathrm{e}}=\frac{\dot{\mathrm{W}}_{\text {net, bcc }}}{\dot{\mathrm{m}}_{\text {fuel }} \mathrm{LHV}_{\text {fuel }}}
$$

\subsubsection{Model Verification}

Although it is not possible to verify the proposed hybrid power model due to its novelty, its constituting elements can be verified separately. The EGC model is verified using the actual operating power plant data supplied by Zorlu Energy. Two standalone part-flow $\mathrm{sCO}_{2}$ cycles are modeled in EBSILON ${ }^{\circledR}$ Professional using the design parameters supplied by Utamura [21] and Mecheri and Moullec [31]. T-s diagrams of the verification models are verified against the T-s diagrams supplied by Utamura [21] and Mecheri and Moullec [31] in Figure 5. The calculated first law efficiencies of $44.6 \%$ and 39\% for the verification models of these two respective studies are in line with their reported values of $45 \%$ and $39 \%$. 


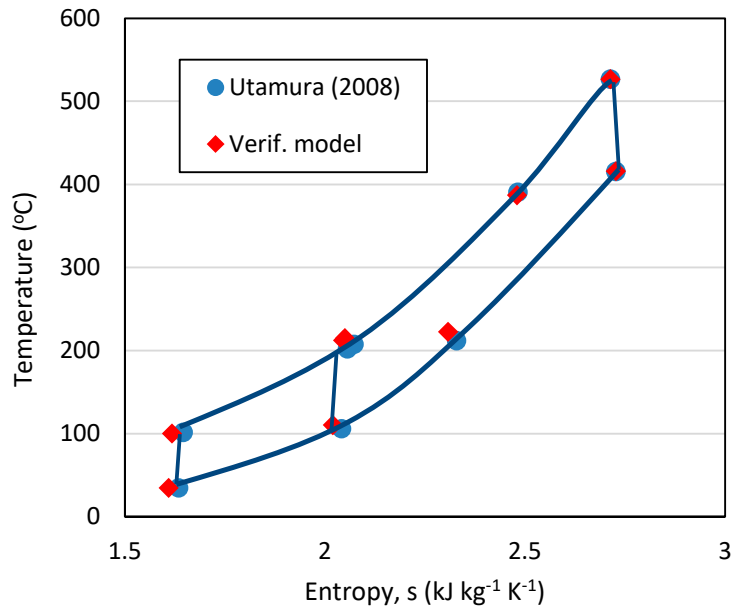

(a)

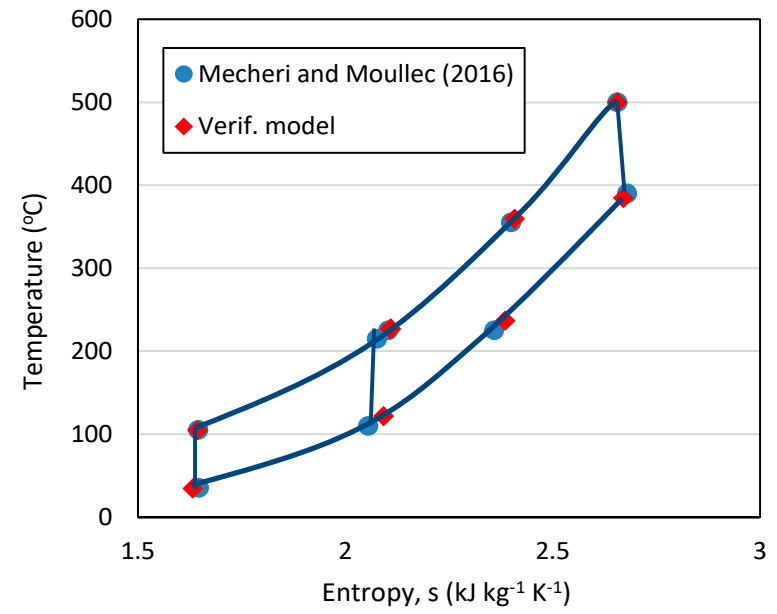

(b)

Figure 5. T-s diagrams of the standalone part-flow $\mathrm{sCO}_{2}$ cycle verification models against the models in the literature: (a) Verification against Utamura [21]; (b) Verification against Mecheri and Moullec [31].

The verification of the radiative-convective BHB model was carried out by creating a verification combustion model in an EbsBoiler module of EBSILON ${ }^{\circledR}$ Professional for the different cases presented in the study of Manente and Lazzaretto [32]. The verification results are presented in Table 3 for $1 \mathrm{~kg} \mathrm{~s}^{-1}$ woody biomass fuel used in their work. Note that the effective temperature of radiation (TEF) and the heat loss in the radiative section is assumed to be $1000{ }^{\circ} \mathrm{C}$ and $5 \%$, respectively, throughout this article, to be consistent with Manente and Lazzaretto [32].

Table 3. BHB verification results based on the model of Manente and Lazzaretto [32].

\begin{tabular}{|c|c|c|c|c|c|c|c|}
\hline \multicolumn{2}{|c|}{ Inputs } & \multicolumn{6}{|c|}{ Outputs } \\
\hline$\lambda$ & $\mathrm{T}_{\text {air }}\left({ }^{\circ} \mathrm{C}\right)$ & $\mathrm{T}_{\text {flue gas }}\left({ }^{\circ} \mathrm{C}\right)$ & $\begin{array}{l}m_{\text {flue gas }} \\
\left(\mathrm{kg} \mathrm{s}^{-1}\right)\end{array}$ & $\mathrm{X}_{\mathrm{CO} 2}$ & $\mathrm{X}_{\mathrm{H} 2 \mathrm{O}}$ & $\mathrm{X}_{\mathrm{N} 2}$ & $\mathrm{X}_{\mathrm{O} 2}$ \\
\hline \multicolumn{8}{|c|}{ Manente and Lazzaretto [32] } \\
\hline \multirow[t]{2}{*}{1.5} & 20 & 1405 & 8.225 & 0.1826 & 0.0754 & 0.6738 & 0.0682 \\
\hline & 100 & 1457 & & & & & \\
\hline 2.37 & 20 & 1000 & 12.41 & 0.1211 & 0.0499 & 0.7053 & 0.1237 \\
\hline 2.56 & 100 & 1000 & 13.33 & 0.1127 & 0.0465 & 0.7095 & 0.1313 \\
\hline \multicolumn{8}{|c|}{ Verification model } \\
\hline \multirow[t]{2}{*}{1.5} & 20 & 1407 & 8.273 & 0.1820 & 0.0749 & 0.6752 & 0.0679 \\
\hline & 100 & 1458.6 & & & & & \\
\hline 2.37 & 20 & 999.9 & 12.49 & 0.1230 & 0.0496 & 0.7065 & 0.1209 \\
\hline 2.56 & 100 & 1000.7 & 13.41 & 0.1125 & 0.0462 & 0.7107 & 0.1306 \\
\hline \multicolumn{8}{|c|}{ Error: (Verif. Model-Ref.)/Ref. } \\
\hline & & $0.1 \%$ & $0.6 \%$ & $-0.3 \%$ & $-0.7 \%$ & $0.2 \%$ & $-0.4 \%$ \\
\hline & & $0.1 \%$ & & & & & \\
\hline & & $0.0 \%$ & $0.6 \%$ & $1.6 \%$ & $-0.6 \%$ & $0.2 \%$ & $-2.3 \%$ \\
\hline & & $0.1 \%$ & $0.6 \%$ & $-0.2 \%$ & $-0.6 \%$ & $0.2 \%$ & $-0.5 \%$ \\
\hline
\end{tabular}

Considering the match in the T-s diagrams, consistency in thermal efficiencies, and the maximum absolute error of $2.3 \%$ in the BHB verification results, the proposed hybrid configuration in this article is assumed to be modeled accurately.

\subsubsection{Optimization of Input Parameters}

For their $\mathrm{sCO}_{2}$ cycle design for waste heat recovery systems, Manente and Fortuna [47] state that one of the main novelties in the recent literature on hybrid plant layouts is the sharing of some equipment to reduce the number of components. The efforts in this 
article aim to use the existing infrastructure of the KZD-1 GEPP to the fullest extent through sharing the existing steam turbine of KZD-1 with EGC and BBC. Concurrently, hybridization scenarios where the design operating conditions of the existing KZD-1 GEPP are changed by means of an increased steam turbine inlet temperature or the generation of superheat steam through biomass combustion are avoided, as power plant operators are generally not willing to make changes to their design conditions. In this sense, the hybridization exploits the excess steam turbine capacity resulting from the degradation in mass flow of the geothermal steam over the years by using the dry steam derived from biomass combustion in $\mathrm{BBC}$ to partially return the steam turbine to its design operating conditions. The mass flow rate of this additional biomass-derived dry steam is equal to the mass flow rate of the $\mathrm{BBC}$ working fluid, water.

The first optimization is done on the flow rates of BBC and BTC by conducting a twodimensional parametric analysis with three-dimensional output, as presented in Figure 6. In this analysis, the mass flow rate of the BTC is varied from 20 to $50 \mathrm{~kg} \mathrm{~s}^{-1}$ in equal $5 \mathrm{~kg} \mathrm{~s}^{-1}$ increments, while BBC mass flow rate is varied from 6 to $18 \mathrm{~kg} \mathrm{~s}^{-1}$ in even $2 \mathrm{~kg} \mathrm{~s}^{-1}$ increments. The reason BTC flow rate is included in this parametric analysis: BTC is thermally coupled to the BBC. The input parameters of these two cycles are held constant and equal to the values in Table 2, except for part-flow ratio, $\psi$, and turbine expansion ratio, $\varphi$, of BTC. The base inputs for $\psi$ and $\varphi$ are taken as 2.51 and 0.68 , respectively, as suggested by Utamura [21], and are optimized after the mass flow rates are determined.

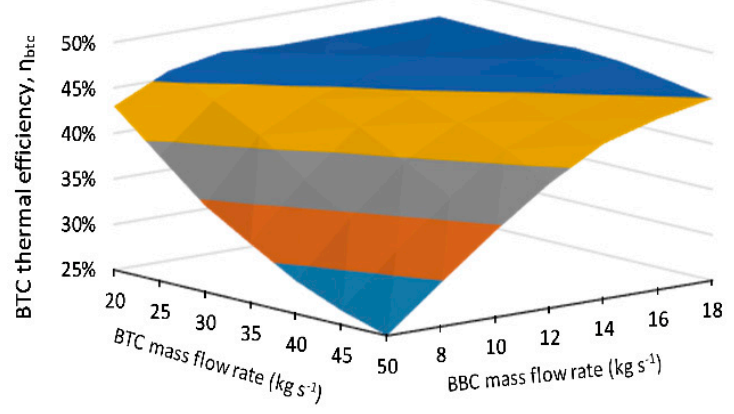

(a)

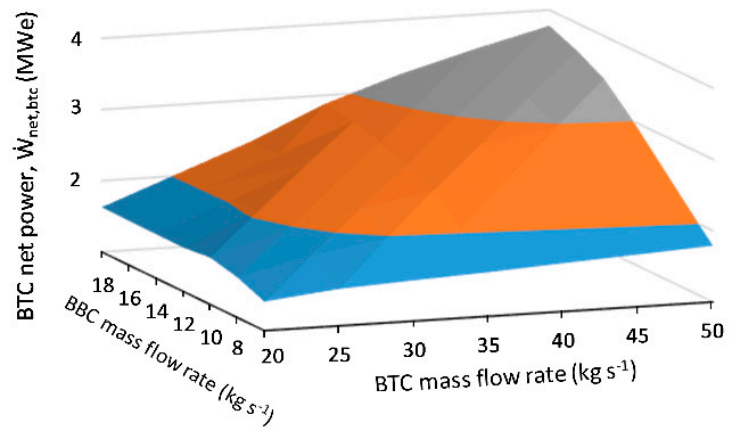

(b)

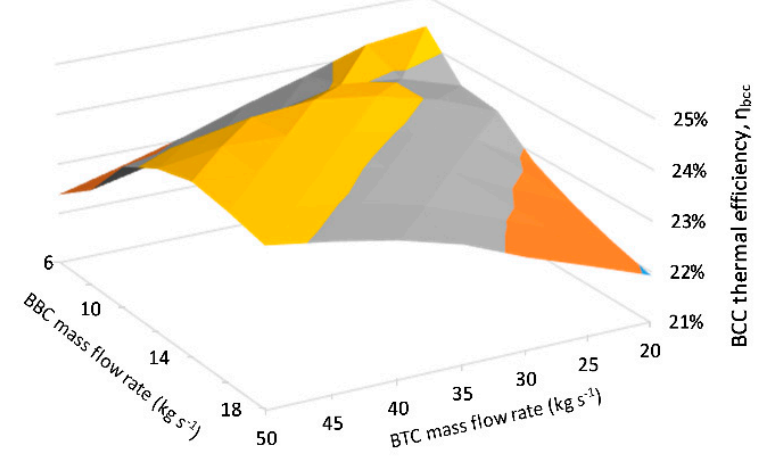

(c)

Figure 6. Results of parametric analysis conducted on the flow rates of BTC and BBC. (a) BTC thermal efficiency, $\eta_{\mathrm{btc}}$; (b) BTC net power output, $\dot{W}_{\text {net,btc }}$ (c) BCC thermal efficiency, $\eta_{\text {bcc }}$.

There are two main outcomes of the conducted analysis in Figure 6. First, the thermal efficiency of BCC in Figure $6 \mathrm{c}$ shows a minima for the maximum flow rate of BTC at $50 \mathrm{~kg} \mathrm{~s}^{-1}$ and minimum flow rate of BBC at $6 \mathrm{~kg} \mathrm{~s}^{-1}$. The underlying reason for this result is the increase in the main compressor $(\mathrm{MC})$ inlet temperature (State 1) of BTC. The increase in $\mathrm{MC}$ inlet temperature is directly proportional to BTC flow rate while being 
inversely proportional to $\mathrm{BBC}$ flow rate for a fixed effectiveness value of the BTC cooler, since the working fluid of $\mathrm{BBC}$ acts as a heat rejection medium for BTC. Note that the reason for utilizing $\mathrm{CO}_{2}$ as a working fluid in a closed-loop power cycle is to exploit the thermophysical properties of $\mathrm{CO}_{2}$ requiring minimum compression work in the vicinity of its critical temperature of $31 .{ }^{\circ} \mathrm{C}$ [48]. Therefore, the efficiency drops as the MC inlet temperature increases. This behavior is also prominent in Figure $6 \mathrm{a}$, where topping cycle efficiency severely drops to $25 \%$. Second, the BCC thermal efficiency exhibits another minima for the minimum flow rate of BTC at $20 \mathrm{~kg} \mathrm{~s}^{-1}$ and maximum flow rate of BBC at $18 \mathrm{~kg} \mathrm{~s}^{-1}$. Note that the BTC thermal efficiency reaches a maximum for this flow rate pair in Figure 6a, whereas BBC thermal efficiency is independent of the flow rates, owing to its fixed intensive thermodynamic properties defined by the KZD-1 steam turbine inlet temperature and constant ambient temperature. The underlying theory leading to this minima in BCC for this flow rate pair is the increase in the power generation share of $B B C$, which has a lower thermal efficiency compared to BTC.

The motivation for the flow rate selection procedure is to maximize BCC thermal efficiency while keeping the scale of BTC as small as possible to minimize the additional equipment cost. Therefore, the flow rate pair of $45 \mathrm{~kg} \mathrm{~s}^{-1}$ and $12 \mathrm{~kg} \mathrm{~s}^{-1}$ is selected for BTC and BBC, respectively. The mass flow rate of the total steam feeding the KZD-1 steam turbine increases from $19.45 \mathrm{~kg} \mathrm{~s}^{-1}$ to $31.45 \mathrm{~kg} \mathrm{~s}^{-1}$ with the addition of the biomass-derived dry steam and brings KZD-1 turbine close to its operation conditions in 2004 [34].

The two-characteristic parameters of BTC, namely, part-flow ratio, $\psi$, and turbine expansion ratio, $\varphi$, are optimized upon the decision of the flow rates. The part-flow ratio represents the ratio of the flow entering main compressor to the total flow; therefore, its unit value represents a simple-recuperated cycle. On the other hand, the turbine expansion ratio, $\varphi$, is the ratio of the turbine inlet pressure to turbine outlet pressure. These ratios not only affect the cycle-level performance parameters such as the thermal efficiency but also dictate the component-level indicators such as the heat duty and pinch point of the recuperators under the condition of constant effectiveness. Optimizations of these ratios are conducted, and the results are presented in Figures 7 and 8. First, the part-flow ratio is varied from 0.6 to 1 in equal 0.05 increments, while all other inputs are kept constant and equal to the values in Table 2, except for the turbine expansion ratio, which is taken at its base value of 2.51 [21]. The part-flow ratio is selected as 0.75 to have the maximum BCC efficiency and minimum cumulative heat duty for the recuperators, while at least $5{ }^{\circ} \mathrm{C}$ pinch point is ensured. Upon the determination and fixing of $\psi$ as 0.75 , the turbine expansion ratio, $\varphi$, is varied from 2 to 4 in even 0.2 increments, while keeping all other inputs equal to their values in Table 2. Similarly, the optimum $\varphi$ as chosen and finalized as 3 to have the maximum possible BCC thermal efficiency and minimum cumulative recuperator heat duty, where at least $5{ }^{\circ} \mathrm{C}$ pinch point is ensured for each recuperator.

The last optimization is done on the intermediate steam quality of the BBC (State 18). Since BHB design is discrete from the cycles, as discussed in Section 2.1.3., the intermediate steam quality does not affect the cycle parameters but is used as a boundary condition to determine the size of radiative and convective sections of the BHB. The preheated water at State 17 is heated by means of radiative combustion, to the intermediate steam quality in the radiative section of $\mathrm{BHB}$. In addition to determining the size of the radiative and convective sections of $\mathrm{BHB}$, this intermediate quality controls the temperature of the flue gas that is utilized in the convective section of the BHB. The results of the parametric study conducted on this intermediate steam quality imply, in Figure 9, that as more radiative heat is used to increase the intermediate steam quality, the temperature of the flue gas decreases. In order to keep the flue gas temperature below $1000{ }^{\circ} \mathrm{C}$, as suggested by Strzalka et al. [49], and have a typical heat distribution in the range of radiation chamber (45-55\%; convective Section $45-25 \%$; stack and other heat losses: $10-20 \%$, as suggested by Stehlík et al. [50]), the intermediate steam quality is chosen to be 0.4 . Note that the retention of a flue gas temperature below $1000{ }^{\circ} \mathrm{C}$ is achieved either by increasing the excess air ratio [32] or recirculating the flue gas inside the furnace [49] in the literature. In this article, 
temperature control of the flue gas is controlled through the intermediate steam quality at State 18. However, a novel biomass heater-boiler design, to supply heat to two power cycles with different working fluids, is beyond the scope of this article and may require further investigation.

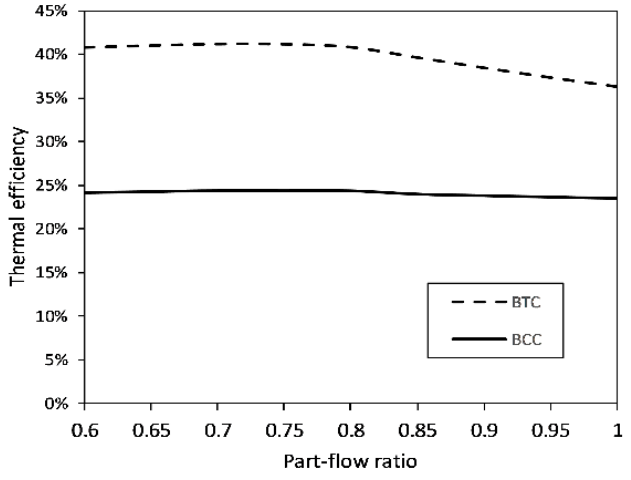

(a)

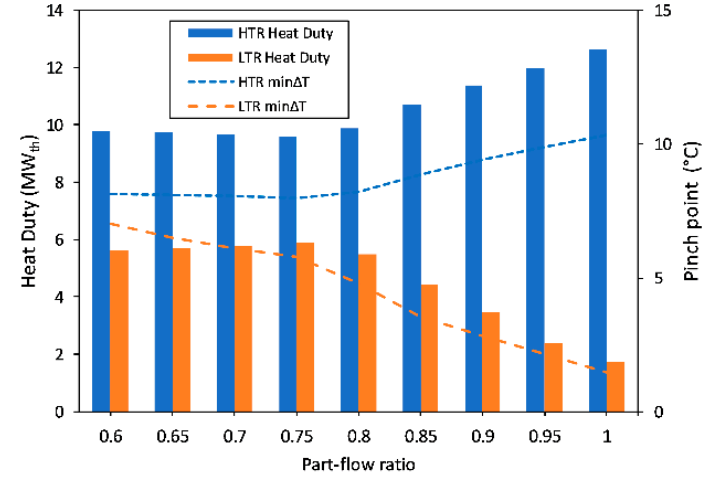

(b)

Figure 7. Optimization of part-flow ratio: (a) Variations in BTC and BCC thermal efficiencies with changing part-flow ratio; (b) Variations in the heat duties and pinch point of the recuperators with changing part-flow ratio.

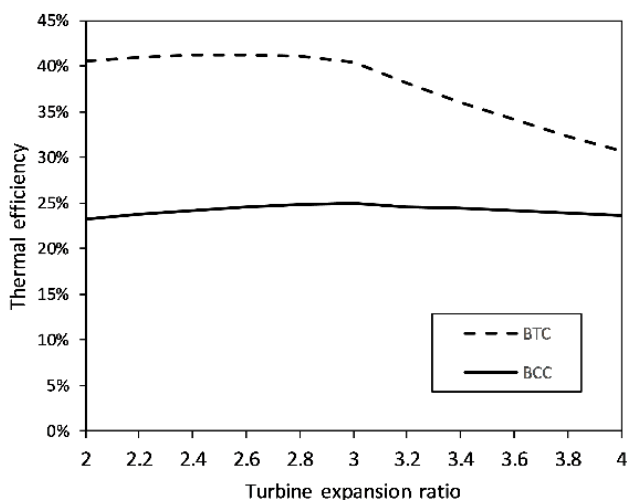

(a)

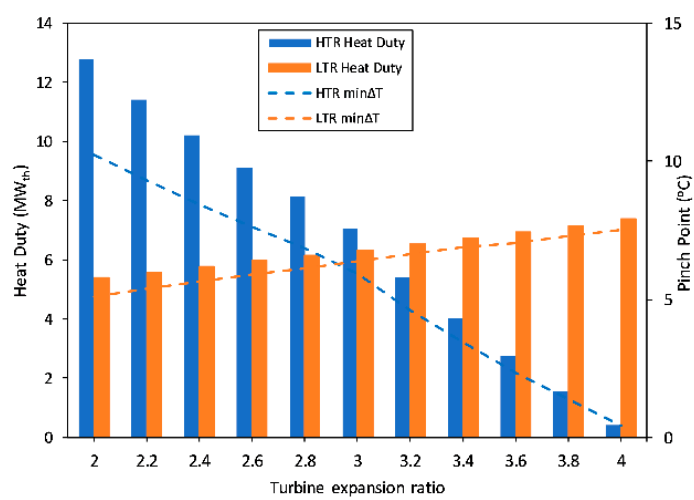

(b)

Figure 8. Optimization of turbine expansion ratio: (a) Variations in thermal efficiencies of BCC and BTC with changing turbine expansion ratio; (b) Variations in the heat duties and pinch point of the recuperators with changing turbine expansion ratio.

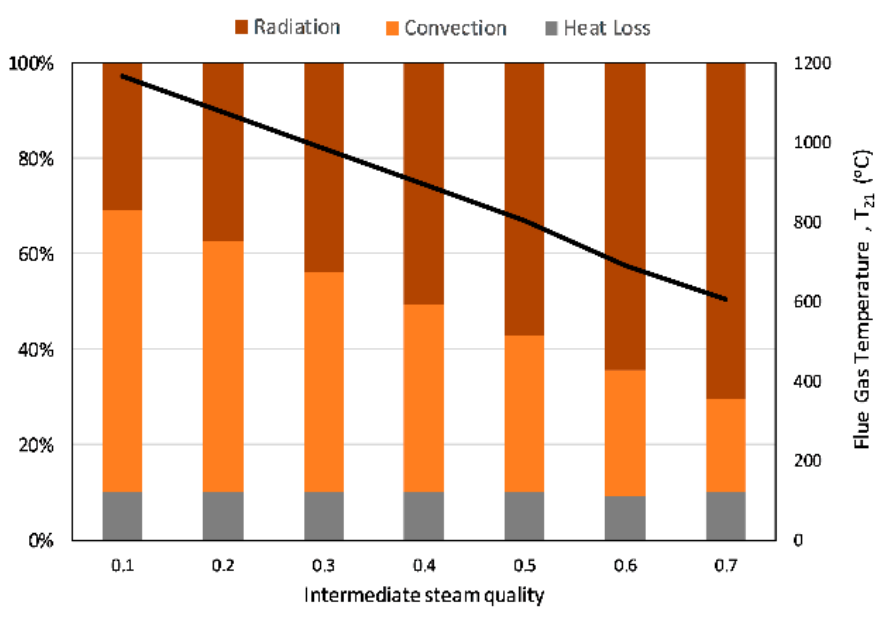

Figure 9. Heat transfer distribution and the flue gas temperature leaving the radiative section of the BHB (State 21) with varying intermediate steam quality. 


\section{Results and Discussion}

The energetic results of the cycles used in the hypothetical hybridization scenario of KZD-1 GEPP are presented in Table 4. The design parameters are provided in Table 2 for reproducibility of the results. T-s diagrams of BTC and BBC are shown in Figure 10.

Table 4. Energetic results of the cycles used in hybridization of KZD-1 GEPP.

\begin{tabular}{|c|c|c|c|}
\hline Cycle & $\underset{\mathrm{kg} \mathrm{s}^{-1}}{\dot{\mathbf{m}}}$ & $\begin{array}{c}\eta_{\text {th }} \\
\%\end{array}$ & $\begin{array}{l}\dot{\mathbf{W}}_{\text {net }} \\
\mathbf{M W e}\end{array}$ \\
\hline Topping part-flow sCO $\mathrm{s}_{2}(\mathrm{BTC})$ & 45 & 40.1 & 3.4 \\
\hline Bottoming steam Rankine (BBC) & 12 & 16.9 & 5.3 \\
\hline Combined $(\mathrm{BCC})$ & - & 24.9 & 8.7 \\
\hline
\end{tabular}

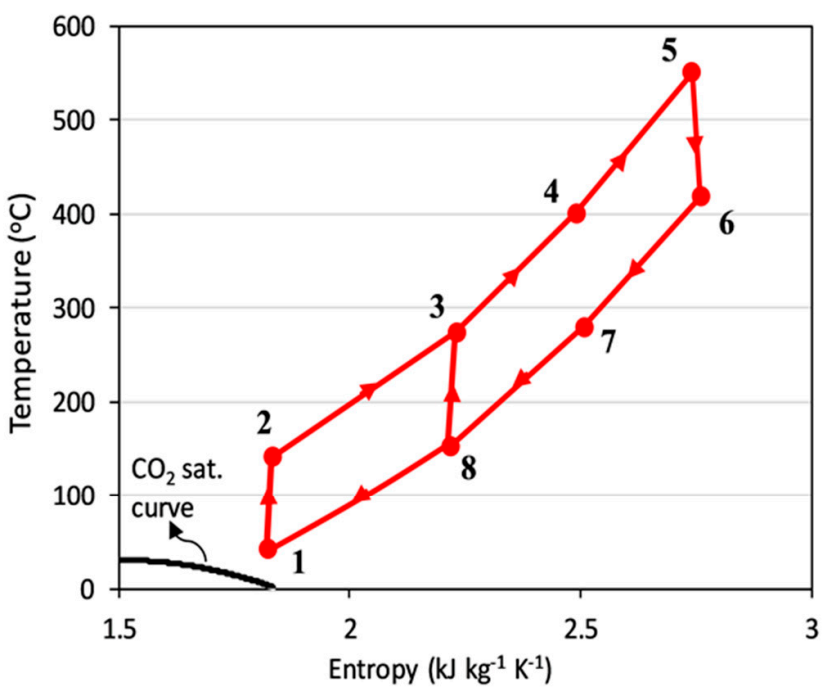

(a)

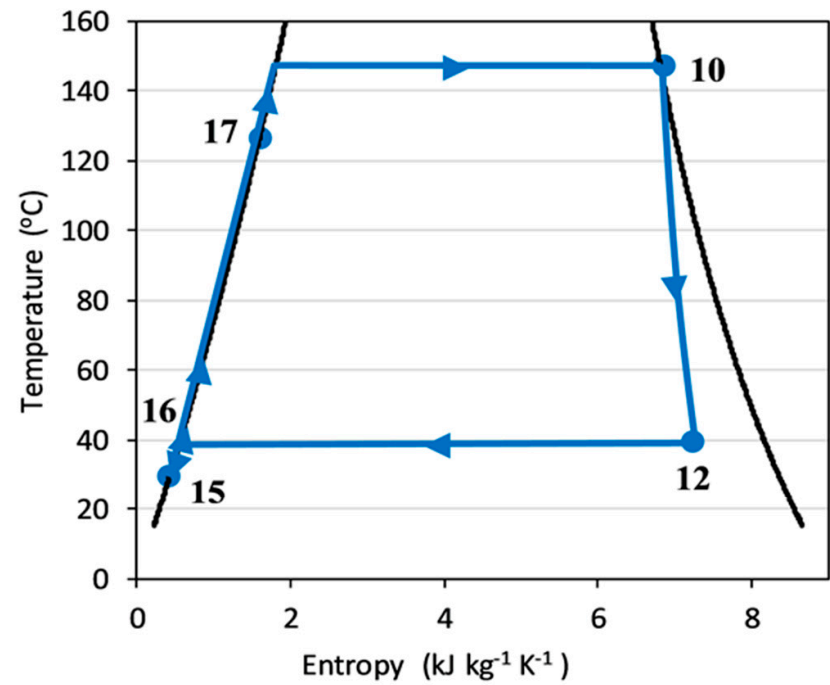

(b)

Figure 10. T-s diagrams of the thermodynamic cycles used in hybridization of KZD-1 GEPP: (a) BTC; (b) BBC.

The thermal efficiency of the standalone part-flow $\mathrm{sCO}_{2}$ cycle with the same turbine inlet temperature (TIT) of $550{ }^{\circ} \mathrm{C}$, as in this article, is reported to be around $46.5 \%$ in the literature [22]. In this work, it is expected that the efficiency of topping the $\mathrm{sCO}_{2}$ cycles will be penalized slightly to maximize the performance of the combined cycle. However, the efficiency penalty of more than $5 \%$ exceeds this expectation. For example, the part-flow $\mathrm{sCO}_{2}$ topping cycle in the study of Manente and Lazzaretto [32] has $44.2 \%$ thermal efficiency for the same maximum turbine inlet conditions as given in this article. The underlying theory leading to an overly penalized BTC efficiency in this article is the deviation from optimum compressor inlet conditions at State 1 . The $\mathrm{sCO}_{2}$ cycles take advantage of the minimal compression work of the working fluid $\mathrm{CO}_{2}$ in the vicinity of its critical temperature of $31.8^{\circ} \mathrm{C}$. Note that the temperature of State 1 in this paper is $42.9^{\circ} \mathrm{C}$, which causes the T-s diagram of the topping cycle to shift slightly right of the saturation curve of $\mathrm{CO}_{2}$ and ultimately decreases the cycle efficiency by about $5 \%$ compared to results in the literature. The reason for the deviation from the optimum $\mathrm{CO}_{2}$ compression inlet temperature is that the rejected heat of BTC is recovered in $\mathrm{BCC}$ using the coupling heat exchanger, cooler. As the flowrate of the $\mathrm{BBC}$ increases, the temperature of the $\mathrm{CO}_{2}$ at the hot side outlet of cooler (State 1) increases under a fixed effectiveness value of the cooler. Although this process penalizes the efficiency of BTC by around $5 \%$, it allows for the utilization of $5 \mathrm{MW}$ thermal heat in the bottoming cycle. In fact, the scale of the topping cycle should be kept as small as possible to use the existing steam turbine of KZD-1 by $\mathrm{BBC}$ to the fullest extent. Therefore, the efficiency drop in BTC is diluted in the combined 
cycle due to the utilization of a significant portion of the biomass-derived heat in BCC, as shown in Figure 11. As a comparison, the net power distribution in the work of Manente and Lazzaretto [32] favors the topping cycle by $90 \%$ (topping) to $10 \%$ (bottoming), while the bottoming cycle is favored in this article by $61 \%$ (bottoming) to $39 \%$ (topping).

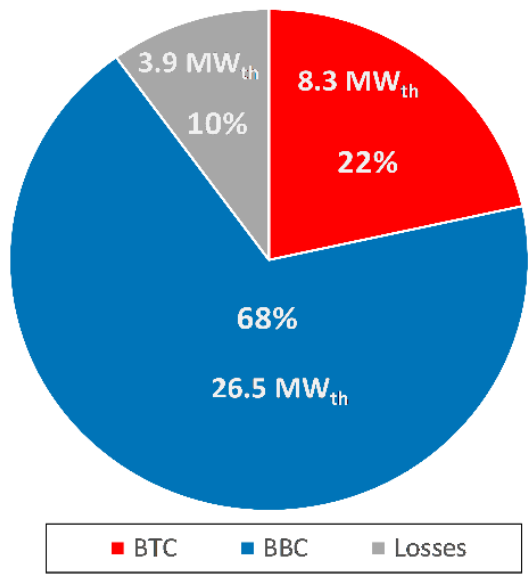

(a)

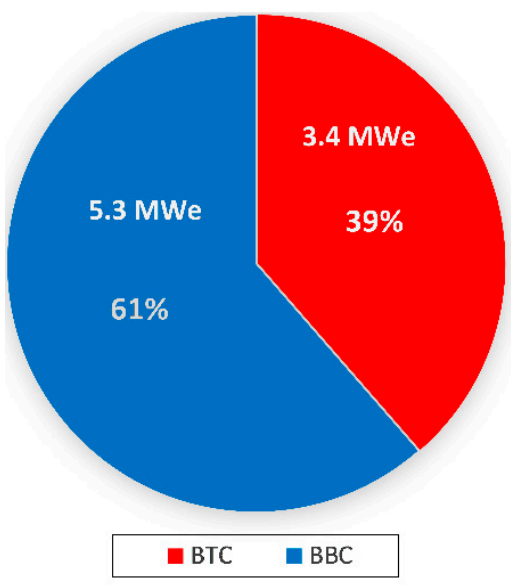

(b)

Figure 11. Heat and power distribution between the cycles: (a) Allocation of biomass energy; (b) Net power distribution.

The thermal efficiency of the single-flash GEPPs with a TIT of $150{ }^{\circ} \mathrm{C}$ lies in the range of $15-18 \%$ in the literature [51]. Although the $16.9 \%$ thermal efficiency of BBC falls in this range, $24.9 \%$ thermal efficiency of BCC can be considered to be penalized itself, due to its favoring BBC in biomass energy utilization, as seen in Figure 11a. There is no similar combined cycle configuration in the literature where $\mathrm{SCO}_{2}$ and steam Rankine cycles are utilized in a cascaded manner, as in this article, to allow for a comparison of BCC thermal efficiency. However, Jiang et al. reported a hybrid solar thermal-EGS power plant using $\mathrm{CO}_{2}$ as a working fluid as reaching $21.93 \%$ and $22.44 \%$, respectively, for TITs of $500{ }^{\circ} \mathrm{C}$ and $600{ }^{\circ} \mathrm{C}$, which is in relatively good agreement with the found BCC efficiency [15]. On the other hand, Manente and Lazzaretto reported their biomass-to-electricity conversion efficiency as $34.3 \%$ for their combined cycle [32]. Despite their topping cycle being a partflow $\mathrm{sCO}_{2}$ cycle with the same turbine inlet conditions as in this article, it should be noted that their bottoming cycle is a simple recuperated $\mathrm{sCO}_{2}$ cycle with a TIT of $313.9^{\circ} \mathrm{C}$, while the TIT of the bottoming steam Rankine cycle in this article is restricted by the operational TIT of KZD-1 GEPP at $146.9^{\circ} \mathrm{C}$. Therefore, a lower biomass-to-electricity conversion efficiency is expected in this article, compared to their $34.3 \%$ conversion efficiency.

Within the scope of this article, the mass flow rate of the biomass fuel in BHB is adjusted so that the temperature of the exhaust flue gas at air preheater outlet (State 23) is limited to the minimum allowable temperature of $110^{\circ} \mathrm{C}$ to prevent dew point condensation after the demanded heat is supplied to the combined cycle [31]. The results of the BHB parameters, including flue gas mass flow rate, flue gas temperature leaving the radiative section of BHB at State 21, flue gas composition, calculated adiabatic flame temperature, and the BHB efficiency, are presented in Table 5. Based on the mass flow rate of the biomass fuel, the biomass-to-electricity conversion efficiency is calculated as $22.4 \%$ using Equation (12).

Table 5. Radiative-convective counter-current heater-boiler (BHB) results.

\begin{tabular}{|c|c|c|c|c|c|c|c|c|}
\hline$\eta_{b h b}$ & $\begin{array}{c}\dot{\mathrm{m}}_{\text {fuel }} \\
\left(\mathrm{kg} \mathrm{s}^{-1}\right)\end{array}$ & $\begin{array}{l}\dot{\mathbf{m}}_{\text {flue gas }} \\
\left(\mathrm{kg} \mathrm{s}^{-1}\right)\end{array}$ & $\begin{array}{l}\text { TAF } \\
\left({ }^{\circ} \mathrm{C}\right)\end{array}$ & $\begin{array}{l}\mathrm{T}_{21} \\
\left({ }^{\circ} \mathrm{C}\right)\end{array}$ & $\mathrm{X}_{\mathrm{CO} 2}$ & $X_{\mathrm{H} 2 \mathrm{O}}$ & $X_{N 2}$ & $\mathrm{x}_{\mathrm{O} 2}$ \\
\hline 0.90 & 2.2 & 21.5 & 1623 & 890.6 & 0.1775 & 0.0623 & 0.6909 & 0.0693 \\
\hline
\end{tabular}


Even though this paper lacks economic and exergy analysis, preliminary remarks can be made on the Q-T diagrams of the heat exchangers presented in Figure 12. For the recuperators, it is shown that no pinch problem exists, and the minimum temperature difference between two streams is kept larger than $5{ }^{\circ} \mathrm{C}$, with an effectiveness of $96 \%$. Although it is expected that the recuperators will have a good temperature match between the cold and hot flows, as they have the same working fluid on both sides, the good temperature match for the cooler is promising in terms of its low potential for exergy destruction, and stems from the fact that water is sensibly heated through the cooler. Since the cooler acts as a thermal coupling mechanism between BTC and BBC, it can be suggested that a good synergy between the two intrinsically different cycles is achievable.

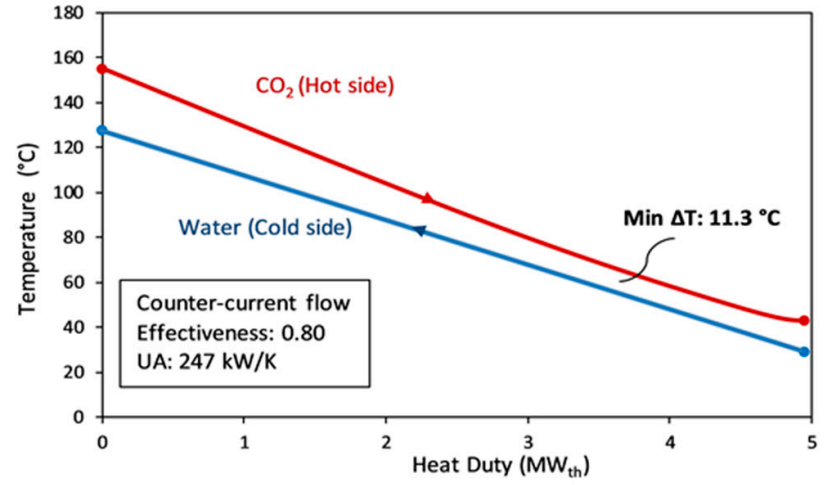

(a)

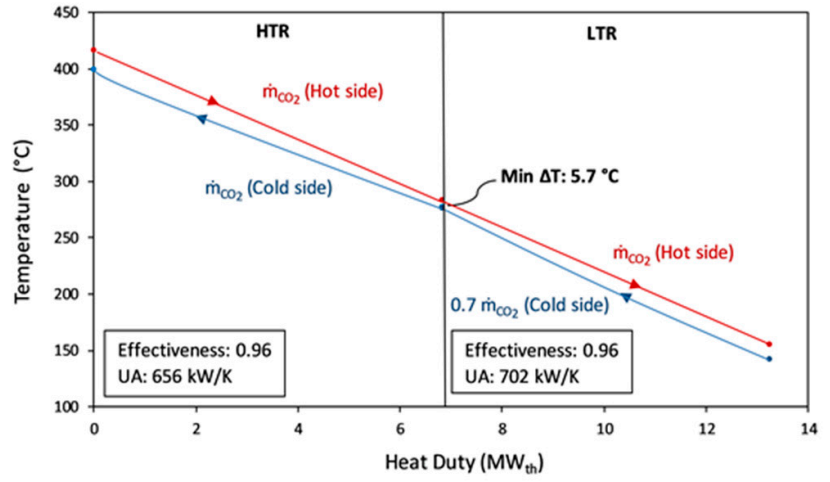

(b)

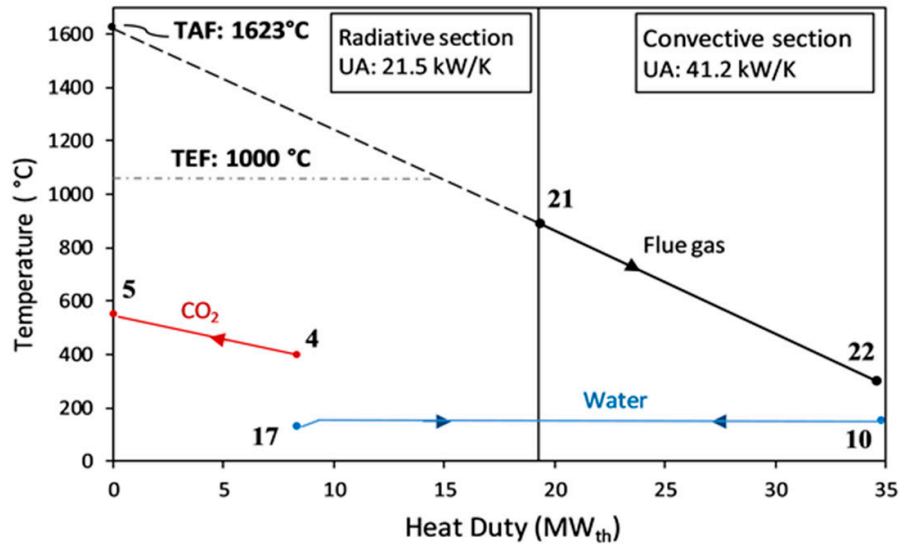

(c)

Figure 12. Q-T diagram of the heat exchangers. (a) Cooler; (b) Recuperators; (c) Radiative-convective counter-current heater-boiler $(\mathrm{BHB})$ with assumed TEF $=1000^{\circ} \mathrm{C}$.

The heat addition to BTC in this article is only possible between state points 4 and 5 in Figure 11a owing to the highly recuperative characteristics of the $\mathrm{sCO}_{2}$ cycles. Thus, heating below a certain temperature, i.e., $400{ }^{\circ} \mathrm{C}$ in this article, cannot be utilized in the topping $\mathrm{SCO}_{2}$ cycle without changing its layout or adding additional heat exchangers. In order to overcome this problem, $\mathrm{sCO}_{2}$ cycles are generally utilized in the literature in a cascaded manner, as mentioned in Sections 1 and 2. Since a flue gas heat below $400{ }^{\circ} \mathrm{C}$ is utilized in $\mathrm{BBC}$ through the convective section of $\mathrm{BHB}$, the problem of having a complex $\mathrm{sCO}_{2}$ cycle layout or adding another $\mathrm{sCO}_{2}$ cycle as a bottoming cycle is resolved. Finally, UA values (commonly known as conductance and expressed in units of $\mathrm{kW} \mathrm{K}^{-1}$ ) for each heat exchanger are supplied as a preliminary economic indicator. It is assumed that the equipment cost scale is within the UA value; recuperators appear to be the heat exchanger units requiring most of the investment costs [44,47]. 


\section{Conclusions}

In this article, the underperforming KZD-1 GEPP is theoretically hybridized using a biomass-driven $\mathrm{sCO}_{2}$ topping and steam Rankine bottoming cycles where locally sourced olive residue is used as a biomass fuel source. While a topping $\mathrm{sCO}_{2}$ cycle is specifically chosen due to its potential for flexible electricity generation, as a first step to develop this novel hybridization scheme, only the steady-state design conditions of hybridization are modeled in this work. The proposed working fluid mass flow rates for topping and bottoming cycles, i.e., $45 \mathrm{~kg} \mathrm{~s}^{-1}$ and $12 \mathrm{~kg} \mathrm{~s}^{-1}$, respectively, can represent the nominal case. For off-design scenarios, these flow rates can be downscaled proportionally by controlling the combusted biomass fuel flow, such that the intensive thermodynamic properties remain close to their design values. Although a decrease in both thermal efficiency and power generation can occur for off-design calculations, the scenarios for hourly fluctuations or seasonal variations can be investigated in future work.

The hybridization increases the nominal flow rate of the steam feeding the KZD-1 turbine from $19.45 \mathrm{~s}^{-1}$ to $31.45 \mathrm{~s}^{-1}$ and brings the steam turbine closer to its operating conditions reported in 2004 [34]. Then, 3.4 MWe and 5.3 MWe additional net powers are generated through the topping and bottoming cycles, with $40.1 \%$ and $16.9 \%$ thermal efficiencies, respectively. The combined cycle composed of the combination of topping and bottoming cycle has a thermal efficiency of $24.9 \%$ and net power generation of $8.7 \mathrm{MWe}$. Biomass to electricity conversion efficiency is calculated as $22.4 \%$ for a fuel consumption rate of $2.2 \mathrm{~kg} \mathrm{~s}^{-1}$. Despite the penalties in terms of topping cycle thermal efficiency and biomass-to-electricity conversion efficiency compared to the literature, the motivation in the hybridization scenario in this article is using the existing infrastructure of KZD-1 GEPP to the fullest extent by keeping the topping cycle and additional investments costs as small as possible while retaining the maximum possible efficiency. In this context, the goal of sharing existing components in hybrid power plant layouts is arguably achieved [47]. Moreover, the high-temperature heat addition problem of $\mathrm{sCO}_{2}$ cycles is resolved by utilizing a flue gas heat under $400{ }^{\circ} \mathrm{C}$ in the bottoming cycle. Consequently, the need to add a bottoming $\mathrm{sCO}_{2}$ cycle or have a complex $\mathrm{sCO}_{2}$ cycle layout is avoided.

The hybridization of an existing GEPP in this article is achieved by the addition of a sCO $\mathrm{CO}_{2}$ cycle, a biomass heater boiler, and a dry cooling system. Although reliable cost correlation parameters of conventional systems, such as boilers or dry cooling systems, are present in the literature for economic analysis, the equipment costs of next-generation $\mathrm{sCO}_{2}$ power cycles that have not been commercialized yet remain unknown. As a rough estimation, Wright et al. consider the cost of all heat exchangers in the $\mathrm{sCO}_{2}$ cycle (recuperators, primary heat exchangers, preheaters, etc.) as about $50 \%$ of the total system costs [52]. Even if a complete economic analysis is not incorporated in this article, UA values of the heat exchangers are supplied in Figure 12 as an economic indicator, and $\mathrm{sCO}_{2}$ recuperators seem to be the components that would account for most of the additional investment costs of such a hybridization.

Although this paper considers a KZD-1 GEPP hybridization scenario as a case study, the results can be adapted to different locations, e.g., to a single-flash GEPP in Philippines using a rice husk as the fuel source. In fact, there would be no need to create a hypothetical bottoming steam Rankine cycle, as in this article, if such a single-flash GEPP works in the cyclic mode contrary to the open-cycle case of KZD-1 GEPP. In that case, the existing closed-loop steam Rankine cycle can be used as the bottoming cycle and offer even better thermal and cost efficiency, since the existing unused cooling system can be utilized and the need for an additional dry cooling system is eliminated.

Author Contributions: Conceptualization, B.M.; methodology, B.M.; software, B.M.; validation, B.M.; formal analysis, D.B.; investigation, D.B and F.K.; data curation, B.M.; writing-original draft preparation, B.M.; writing-review and editing, B.M., D.B. and F.K.; visualization, B.M. and D.B.; supervision, D.B. and F.K.; project administration, D.B.; funding acquisition, D.B. All authors have read and agreed to the published version of the manuscript. 
Funding: This research is funded by EU H2020 Project GeoSmart: Technologies for geothermal to enhance competitiveness in smart and flexible operation under Grant Agreement number 818576 website: geosmartproject.eu.

Data Availability Statement: The data presented in this study are available on request from the corresponding author.

Acknowledgments: Authors would like to thank Zorlu Energy, one of the partners within GeoSmart project, for their help on sharing operational data of their power plant.

Conflicts of Interest: The authors declare no conflict of interest.

$\begin{array}{ll}\text { Abbreviations/Nomenclature } \\ \text { b2e } & \text { biomass to electricity } \\ \text { BBC } & \text { biomass bottoming cycle } \\ \text { BCC } & \text { biomass combined cycle } \\ \text { BHB } & \text { biomass heater boiler } \\ \text { BTC } & \text { biomass topping cycle } \\ \text { CSP } & \text { concentrated solar power } \\ \text { DC } & \text { direct contact } \\ \text { DSG } & \text { direct steam generation } \\ \text { EGS } & \text { enhanced geothermal system } \\ \text { GEPP } & \text { geothermal electric power plant } \\ \text { HHV } & \text { higher heating value } \\ \text { HP } & \text { lower heating value } \\ \text { HTR } & \text { High-temperature recuperator } \\ \text { KZD-1 } & \text { Kizldere- } 1 \\ \text { KZD-2 } & \text { Kizlldere- } 2 \\ \text { LCOE } & \text { levelized cost of electricity } \\ \text { LHV } & \text { lower heating value } \\ \text { LP } & \text { low pressure } \\ \text { LTR } & \text { Low-temperature recuperator } \\ \text { MC } & \text { main compressor } \\ \text { NGC } & \text { non-condensable gas } \\ \text { OR } & \text { olive residue } \\ \text { ORC } & \text { organic Rankine cycle } \\ \text { PTC } & \text { parabolic trough collector } \\ \text { PV } & \text { photovoltaic } \\ \text { RC } & \text { recompressor } \\ \text { sCO } & \text { supercritical CO } \\ \text { TAF } & \text { adiabatic flame temperature } \\ \text { tCO } & \text { transcritical CO } \\ \text { TEF } & \text { effective temperature of radiation } \\ \text { TIT } & \text { turbine inlet temperature } \\ \text { WCT } & \text { wet cooling tower } \\ \text { WHR } & \text { waste heat recovery } \\ \lambda & \text { excess air ratio } \\ & \end{array}$

\section{References}

1. Wendt, D.S.; Mines, G.L. Use of a geothermal-solar retrofit hybrid power plant to mitigate declines in geothermal resource productivity. Trans. Geotherm. Resour. Counc. 2014, 38, 825-832.

2. Michaelides, E.E.; Michaelides, D.N. The effect of ambient temperature fluctuation on the performance of geothermal power plants. Int. J. Exergy 2011, 8, 86-98. [CrossRef]

3. Pasqualetti, M.J. The site specific nature of geothermal energy: The primary role of land use planning in nonelectric development. Nat. Resour. J. 1983, 23, 795-814.

4. Borsukiewicz-Gozdur, A. Dual-fluid-hybrid power plant co-powered by low-temperature geothermal water. Geothermics 2010, 39, 170-176. [CrossRef]

5. Briola, S.; Gabbrielli, R.; Bischi, A. Off-design performance analysis of a novel hybrid binary geothermal-biomass power plant in extreme environmental conditions. Energy Convers. Manag. 2019, 195, 210-225. [CrossRef] 
6. Rostamzadeh, H.; Gargari, S.G.; Namin, A.S.; Ghaebi, H. A novel multigeneration system driven by a hybrid biogas-geothermal heat source, Part II: Multi-criteria optimization. Energy Convers. Manag. 2019, 180, 859-888. [CrossRef]

7. Di Pippo, R. Geothermal Power Generation: Developments and Innovation; Woodhead Publishing: Sawston, UK, 2016; ISBN 9780081003442.

8. Li, K.; Liu, C.; Jiang, S.; Chen, Y. Review on hybrid geothermal and solar power systems. J. Clean. Prod. 2020, $250,119481$. [CrossRef]

9. Lentz, Á.; Almanza, R. Solar-geothermal hybrid system. Appl. Therm. Eng. 2006, 26, 1537-1544. [CrossRef]

10. Lentz, Á.; Almanza, R. Parabolic troughs to increase the geothermal wells flow enthalpy. Sol. Energy 2006, 80, 1290-1295. [CrossRef]

11. Mir, I.; Escobar, R.; Vergara, J.; Bertrand, J. Performance Analysis of a Hybrid Solar-Geothermal Power Plant in Northern Chile. In Proceedings of the World Renewable Energy Congress-Sweden, Linköping, Sweden, 8-13 May 2011; pp. 1281-1288. [CrossRef]

12. Cardemil, J.M.; Cortés, F.; Díaz, A.; Escobar, R. Thermodynamic evaluation of solar-geothermal hybrid power plants in northern Chile. Energy Convers. Manag. 2016, 123, 348-361. [CrossRef]

13. McTigue, J.D.; Castro, J.; Mungas, G.; Kramer, N.; King, J.; Turchi, C.; Zhu, G. Hybridizing a geothermal power plant with concentrating solar power and thermal storage to increase power generation and dispatchability. Appl. Energy 2018, 228, 1837-1852. [CrossRef]

14. Bonyadi, N.; Johnson, E.; Baker, D. Technoeconomic and exergy analysis of a solar geothermal hybrid electric power plant using a novel combined cycle. Energy Convers. Manag. 2018, 156, 542-554. [CrossRef]

15. Jiang, P.X.; Zhang, F.Z.; Xu, R.N. Thermodynamic analysis of a solar-enhanced geothermal hybrid power plant using $\mathrm{CO}_{2}$ as working fluid. Appl. Therm. Eng. 2017, 116, 463-472. [CrossRef]

16. Conboy, T.; Wright, S.; Pasch, J.; Fleming, D.; Rochau, G.; Fuller, R. Performance characteristics of an operating supercritical $\mathrm{CO}_{2}$ brayton cycle. J. Eng. Gas Turbines Power 2012, 134, 1-12. [CrossRef]

17. Conboy, T.; Pasch, J.; Fleming, D. Control of a supercritical $\mathrm{CO}_{2}$ recompression brayton cycle demonstration loop. J. Eng. Gas Turbines Power 2013, 135, 1-12. [CrossRef]

18. Angelino, G. Carbon dioxide condensation cycles for power production. J. Eng. Gas Turbines Power 1968, 90, 287-295. [CrossRef]

19. Utamura, M.; Hasuike, H.; Ogawa, K.; Yamamoto, T.; Fukushima, T.; Watanabe, T.; Himeno, T. Demonstration of Supercritical $\mathrm{CO}_{2}$ Closed Regenerative Brayton Cycle in a Bench Scale Experiment. In Proceedings of the ASME Turbo Expo 2012: Turbine Technical Conference and Exposition, Copenhagen, Denmark, 11-15 June 2012; pp. 1-10.

20. Turchi, C.S.; Ma, Z.; Dyreby, J. Supercritical carbon dioxide power cycle configurations for use in concentrating solar power systems. In Proceedings of the ASME Turbo Expo 2012: Turbine Technical Conference and Exposition, Copenhagen, Denmark, 11-15 June 2012; Volume 5, pp. 967-973. [CrossRef]

21. Utamura, M. Thermodynamic analysis of part-flow cycle supercritical $\mathrm{CO}_{2}$ gas turbines. In Proceedings of the ASME Turbo Expo 2008: Power for Land, Sea, and Air, Berlin, Germany, 9-13 June 2008; Volume 2, pp. 423-430. [CrossRef]

22. Crespi, F.; Gavagnin, G.; Sánchez, D.; Martínez, G.S. Supercritical carbon dioxide cycles for power generation: A review. Appl. Energy 2017, 195, 152-183. [CrossRef]

23. Wang, X.; Wu, Y.; Wang, J.; Dai, Y. Thermo-economic Analysis of a Recompression $\mathrm{sCO}_{2} \mathrm{Cycle}_{\text {Combined with a tCO }} \mathrm{Cycle}_{\text {. In }}$ Proceedings of the ASME Turbo Expo 2015: Turbine Technical Conference and Exposition, Montreal, QC, Canada, 15-19 June 2015; pp. 1-11.

24. Wang, X.; Wang, J.; Zhao, P.; Dai, Y. Thermodynamic Comparison and Optimization of Supercritical $\mathrm{CO}_{2}$ Brayton Cycles with a Bottoming Transcritical $\mathrm{CO}_{2}$ Cycle. J. Energy Eng. 2016, 142. [CrossRef]

25. Wu, C.; Yan, X.J.; Wang, S.; Bai, K.L.; Di, J.; Cheng, S.F.; Li, J. System optimisation and performance analysis of $\mathrm{CO}_{2}$ transcritical power cycle for waste heat recovery. Energy 2016, 100, 391-400. [CrossRef]

26. Besarati, S.M.; Goswami, D.Y. Analysis of Advanced Supercritical Carbon Dioxide Power Cycles With a Bottoming Cycle for Concentrating Solar Power Applications. J. Sol. Energy Eng. 2014, 136, 1-7. [CrossRef]

27. Zhang, H.; Shao, S.; Zhao, H.; Feng, Z. Gt2014-26500 Thermodynamic Analysis of a Sco 2 Part-Flow Cycle Combined with Liquefied Natural Gas as Heat Sink. In Proceedings of the ASME Turbo Expo 2014: Turbine Technical Conference and Exposition, Düsseldorf, Germany, 16-20 June 2014; pp. 1-8.

28. Wang, X.; Dai, Y. Exergoeconomic analysis of utilizing the transcritical $\mathrm{CO}_{2}$ cycle and the ORC for a recompression supercritical $\mathrm{CO}_{2}$ cycle waste heat recovery: A comparative study. Appl. Energy 2016, 170, 193-207. [CrossRef]

29. Akbari, A.D.; Mahmoudi, S.M.S. Thermoeconomic analysis \& optimization of the combined supercritical $\mathrm{CO}_{2}$ (carbon dioxide) recompression Brayton/organic Rankine cycle. Energy 2014, 78, 501-512. [CrossRef]

30. Le Moullec, Y. Conceptual study of a high efficiency coal-fired power plant with $\mathrm{CO}_{2}$ capture using a supercritical $\mathrm{CO}_{2} \mathrm{Brayton}$ cycle. Energy 2013, 49, 32-46. [CrossRef]

31. Mecheri, M.; Le Moullec, Y. Supercritical $\mathrm{CO}_{2}$ Brayton cycles for coal-fired power plants. Energy 2016, 103, 758-771. [CrossRef]

32. Manente, G.; Lazzaretto, A. Innovative biomass to power conversion systems based on cascaded supercritical $\mathrm{CO}_{2} \mathrm{Brayton}_{\mathrm{Cycles}}$ Biomass Bioenergy 2014, 69, 155-168. [CrossRef]

33. Di Pippo, R. Geothermal Power Plants; Butterworth-Heinemann: Oxford, UK, 2012; Volume 7, ISBN 9780080878737.

34. Gokcen, G.; Ozturk, H.K.; Hepbasli, A. Overview of Kizildere Geothermal Power Plant in Turkey. Energy Convers. Manag. 2004, 45, 83-98. [CrossRef] 
35. The Turkish Olive Oil Sector. Available online: https://www.olioofficina.it/en/knowledge/economy/the-turkish-olive-685oilsector.htm (accessed on 15 April 2021).

36. Hocaoğlu, S.M.; Haksevenler, H.G.; Baştürk, İ.; Aydöner, C. Zeytin Sektörü Atıklarının Yönetimi Projesi Nihai Rapor; Ministry of Environment and Urbanisation of Turkey: Ankara, Turkey, 2015. Available online: https://webdosya.csb.gov.tr/db/destek/ icerikler/zeyt-n_sektoru_at-klar-n-n_yonet-m-_projes--20191127122437.pdf (accessed on 8 June 2021).

37. Sheng, C.; Azevedo, J.L.T. Estimating the higher heating value of biomass fuels from basic analysis data. Biomass Bioenergy 2005, 28, 499-507. [CrossRef]

38. Magalhães, D.; Kazanç, F.; Riaza, J.; Erensoy, S.; Kabaklı, Ö.; Chalmers, H. Combustion of Turkish lignites and olive residue: Experiments and kinetic modelling. Fuel 2017, 203, 868-876. [CrossRef]

39. Vesely, L.; Dostal, V.; Hajek, P. Design of Experimental Loop With Supercritical Carbon Dioxide. In Proceedings of the 2014 22nd International Conference on Nuclear Engineering, Prague, Czech Republic, 7-11 July 2014; pp. 1-7. [CrossRef]

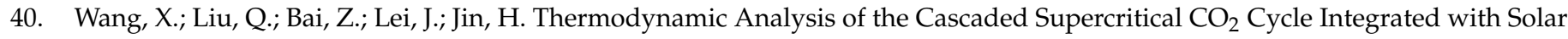
and Biomass Energy. Energy Procedia 2017, 105, 445-452. [CrossRef]

41. Sun, E.; Xu, J.; Li, M.; Li, H.; Liu, C.; Xie, J. Synergetics: The cooperative phenomenon in multi-compressions $\mathrm{S}_{-} \mathrm{CO}_{2}$ power cycles. Energy Convers. Manag. X 2020, 7, 100042. [CrossRef]

42. Turchi, C.S.; Ma, Z.; Neises, T.; Wagner, M. Thermodynamic Study of Advanced Supercritical Carbon Dioxide Power Cycles for High Performance Concentrating Solar Power Systems. In Proceedings of the ASME 2012 6th International Conference on Energy Sustainability collocated with the ASME 2012 10th International Conference on Fuel Cell Science, Engineering and Technology, San Diego, CA, USA, 23-26 July 2012; pp. 375-383. [CrossRef]

43. Siddiqui, M.E.; Almitani, K.H. Energy analysis of the S-CO2 Brayton cycle with improved heat regeneration. Processes 2019, 7, 3. [CrossRef]

44. Neises, T.; Turchi, C. A comparison of supercritical carbon dioxide power cycle configurations with an emphasis on CSP applications. Energy Procedia 2014, 49, 1187-1196. [CrossRef]

45. Kulhánek, M.; Dostál, V. Thermodynamic Analysis and Comparison of Supercritical Carbon Dioxide Cycles. In Proceedings of the Supercritical $\mathrm{CO}_{2}$ Power Cycle Symposium, Boulder, Colorado, 24-25 May 2011; Available online: https:/ / drive.google.com/ file/d/1KcvMoLYNYXxxkbXjJWjSSixKQr4DVhmnHqAFQk-R3mybERAXd3TieAus5QmQ/view (accessed on 7 June 2021).

46. Olumayegun, O.; Wang, M. Dynamic modelling and control of supercritical $\mathrm{CO}_{2}$ power cycle using waste heat from industrial processes. Fuel 2019, 249, 89-102. [CrossRef]

47. Manente, G.; Fortuna, F.M. Supercritical $\mathrm{CO}_{2}$ power cycles for waste heat recovery: A systematic comparison between traditional and novel layouts with dual expansion. Energy Convers. Manag. 2019, 197, 111777. [CrossRef]

48. Cabeza, L.F.; de Gracia, A.; Fernández, A.I.; Farid, M.M. Supercritical $\mathrm{CO}_{2}$ as heat transfer fluid: A review. Appl. Therm. Eng. 2017, 125, 799-810. [CrossRef]

49. Strzalka, R.; Erhart, T.G.; Eicker, U. Analysis and optimization of a cogeneration system based on biomass combustion. Appl. Therm. Eng. 2013, 50, 1418-1426. [CrossRef]

50. Stehlík, P.; Zagermann, S.; Gängler, T. Furnace integration into processes justified by detailed calculation using a simple mathematical model. Chem. Eng. Process. Process Intensif. 1995, 34, 9-23. [CrossRef]

51. Zarrouk, S.J.; Moon, H. Efficiency of geothermal power plants: A worldwide review. Geothermics 2014, 51, 142-153. [CrossRef]

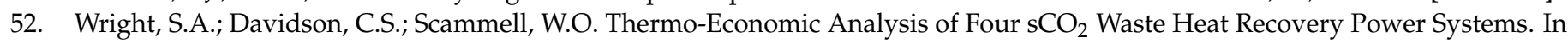
Proceedings of the Fifth International $\mathrm{SCO}_{2}$ Symposium, San Antonio, TX, USA, 29-31 March 2016; pp. 1-16. 